\title{
Path-dependent import-substitution policies: the case of Argentina in the twentieth century
}

\author{
Sebastián Galiani ${ }^{1} \cdot$ Paulo Somaini ${ }^{2,3}$
}

Received: 19 July 2017/Revised: 15 September 2017/ Accepted: 30 September 2017

(C) The Author(s) 2017. This article is an open access publication

\begin{abstract}
We use a simple three-sector model to narrate the economic history of Argentina during the twentieth century as seen through the prism of its integration into and dis-integration from the world economy. Assuming that capital moves between the primary and secondary sectors more slowly than labor moves between the secondary and tertiary sectors, we show that import-substitution policies exhibit path dependence. We contend that the endogenous industrialization of the inter-war period generated political changes that paved the way for import-substitution industrialization during the post-war period. Even if this inward-oriented strategy failed to spur economic growth, protectionist policies became entrenched. In the absence of mature political institutions, the liberalization process was delayed and, when it finally did occur, it was extremely costly.
\end{abstract}

Keywords Trade policy · Import substitution · Trade liberalization · Protectionism

JEL classification $\mathrm{N} 10 \cdot \mathrm{N} 17 \cdot \mathrm{D} 72 \cdot \mathrm{D} 78$

Paulo Somaini

soma@stanford.edu

Sebastián Galiani

galiani@econ.umd.edu

1 Department of Economics, University of Maryland, College Park, MD, USA

2 Stanford Graduate School of Business, Stanford, CA, USA

3 NBER, Cambridge, MA, USA 


\section{Introduction}

Argentina tends to grow relatively faster when its economy is integrated into world markets. Why, then, did it remain closed to world trade for 60 years during the twentieth century? In this paper we contend, like many other authors have in the past (see, among others, Díaz-Alejandro 1970, 1984; Mallon and Sourrouille 1975; O’Donnell 1977; Waisman 1987; Rogowski 1989; Gerchunoff 1989; Taylor 1994; Gerchunoff and Llach 2004), that a severe distributional conflict lies at the core of this phenomenon. In Argentina, for a large part of the twentieth century, what was efficient was not popular. In the words of one insightful economic historian of the Argentine Republic:

"... Argentina is too transparently a Stolper-Samuelson country where a zerosum view of economic policy is plausible in the short and even the medium term" (Díaz-Alejandro 1984).

The ideas behind the Stolper-Samuelson theorem explain the increasingly pronounced urban-rural political cleavage seen in the aftermath of the Second World War; however, they do not explain the process of integration into world markets. We show that these processes can be understood once we add a nontradable sector and frictions in the mobility of capital across sectors. Under these conditions, free trade can benefit all factors of production. However, even if that is the case, protectionism may persist if political institutions are not able to enforce long-term agreements between political actors.

Up to the 1930s, Argentina was well integrated into the world economy and, although some protectionism naturally arose in the wake of the worldwide crisis of the 1930s, it was only after the Second World War that the country closed its economy off from world markets and then remained in a situation close to autarky until the mid-1970s. It was only after a long period of absolute economic decline and devastating hyperinflation that an intensive program of reform and integration into the world economy was adopted.

In this paper, we present a simple three-sector model to narrate the economic history of Argentina during the twentieth century as seen through the prism of its integration into and dis-integration from the world economy. In our model, the primary sector uses land and capital to produce agricultural goods; the secondary sector employs labor and capital to produce manufactured or industrial goods; and the tertiary sector uses only labor to produce services. We assume that (as in fact is the case) Argentina has a comparative advantage in the production of agricultural goods. Thus, the economy exports agricultural goods and imports manufactured goods; services are non-tradable and are always produced in equilibrium. The government's intervention in the economy is limited to taxing trade and distributing the proceeds among the relevant agents.

We characterize the steady-state equilibria of this economy and show that the economy could operate under specialization and trade, where neither labor nor capital is employed to produce manufactured goods; under diversification and trade, where the manufacturing sector is active in production; or under autarky, where there is no trade (for the sake of completeness, we also show that there are other equilibria where the patterns of trade reverse). 
We focus on the functional distribution of income; therefore, we consider three socioeconomic groups: workers, landowners and capitalists. We use our model to characterize these different groups' demands for protectionist policies. Assuming that capital moves between the primary and secondary sectors more slowly than labor moves between the secondary and tertiary sectors, we show that importsubstitution policies exhibit path dependence. Indeed, this is a very important insight into understanding the economic history of Argentina.

Using the insights derived from our model, we then argue that much of the distributional conflict that arose during that period was among owners of different production factors and that trade policies were widely used to shift income across groups. At the beginning of the century, the country specialized in the production of primary goods and was highly integrated into world trade. During the inter-war period, trade opportunities and the terms of trade worsened and this led to an incipient industrialization process. Argentina started the second half of the century with a very different economic configuration. Industrialization had come a long way, and integration into world markets was weak. These new economic conditions also changed the political equilibrium; urban workers employed in the manufacturing sector and industrialists were now major social actors and they were demanding protectionist policies. Traditional sectors comprising owners of factors employed in the primary sector, on the other hand, supported free trade policies. This distributional conflict surrounding trade policy shaped the politics of the second half of the century.

The years that followed the Second World War were a time of an extraordinarily rapid expansion of trade, in which Argentina was not an active participant. Instead, it embarked on an ambitious process of import-substitution industrialization that resulted in bumpy cycles of economic expansion followed by sharp recessions. Argentina had the opportunity to return to an export-led growth strategy, but the new political forces that emerged from the industrialization process during the interwar period were able to block any attempt to liberalize.

Liberalization could have been achieved gradually, thus mitigating the losses of those with vested interests in protected activities. However, it would have required a set of political institutions capable of enforcing intertemporal agreements between political groups. Sadly, Argentina lacked such institutions (see Spiller and Tommasi 2009). Instead, the dismantlement of the import-substitution strategy came only after a substantial deterioration of economic and political conditions. The steps that were then taken toward liberalization were abrupt and applied as shock policies by political groups that had political power but that did not represent a consensus of the Argentine population. As a result, Argentina's integration into world markets proved to be extremely costly in terms of inequality and poverty.

Our main thesis is that the interplay of economic and political forces that were spurred by international conditions during the inter-war period trapped the country into an anti-trade equilibrium which limited economic growth. The conditions that generated the anti-trade trap in Argentina, however, should have also generated the same effect in other new-settler, land-rich economies. This poses a pressing question: Was Argentina the only economy that fell into an anti-trade trap? We argue that most economies that shared the endowment configuration of Argentina 
faced a distributional conflict of similar characteristics, but with different intensities and outcomes.

The rest of the chapter is organized as follows. In Sect. 2, we relate our work with the existing literature and explain why we focus on trade policy. In Sect. 3, we set up and solve the model. In Sect. 4, we interpret the economic history of Argentina during the twentieth century as seen through the prism of our model. In Sect. 5, we compare Argentina with another new-settler, land-rich economy: Australia. Finally, in Sect. 6, we present our conclusions.

\section{Why is trade policy important?}

There is a vast amount of literature on the decline of Argentina during the twentieth century, and a wide variety of factors have been identified as causes of its dismal economic performance. However, there is broad agreement in the literature that this period was marked by a severe distributional conflict that shaped the politics and the economics of the country (see, among others, Díaz-Alejandro 1970, 1984; Mallon and Sourrouille 1975; O’Donnell 1977; Waisman 1987; Rogowski 1989; Gerchunoff 1989; Taylor 1994; Gerchunoff and Llach 2004).

Essays on Argentine economic history usually describe, in more or less detail, the periods of economic crisis that alternated with stability and recovery; this is usually referred to as a "stop-and-go" process (see Díaz-Alejandro 1970; Mallon and Sourrouille 1975; Gerchunoff and Llach 2004). These authors note that the crises were usually caused by overvaluation of the domestic currency, high inflation and current account deficits, whereas stabilization generally involved some combination of fiscal austerity, devaluation and price controls. Once the economy had been stabilized, the government resumed its profligate behavior which led inevitably to yet another "stop". These stop-and-go cycles were closely linked to the real exchange rate or to the relative price of tradables versus non-tradables; stabilization required a real devaluation, whereas government deficits generated real appreciation.

We will focus on a different relative price: the terms of trade, i.e., the price of exports relative to the price of imports. We will also discuss the effect of protectionism on such relative prices as perceived by economic actors. To isolate the analysis from the effect of the real exchange rate, we build a model in which there is no debt and the trade balance has to be balanced in every single period.

The real exchange rate is a key element in analyzing short-term debt management problems, short-term capital flows and agents' perceived wealth (Heymann 1984). However, long-run trends in terms of trade and persistent trade policies are key to an understanding of long-term investment and capital reallocation in the economy. Ultimately, these factors are more influential in shaping the political and economic landscape. That is why our narrative deals with general developments over a span of decades rather than delving into the details of each one of the sudden stops that plagued Argentina during this period.

For at least 50 years, successive Argentine governments intentionally distorted producer prices by setting import tariffs and export duties and maintaining a dual 
exchange rate mechanism (see Brambilla et al. (2010) in this volume). These distortions altered the allocation of resources in the economy, which in turn affected the political equilibrium.

Finally, we do not minimize the role of organizations and institutions in shaping the course of history (North 1990; Cortés-Conde 1998). As we argue in this paper, once the import-substitution development strategy had proven to be inefficient, liberalization measures could have been instituted gradually to mitigate the losses of those with vested interests in protected activities. A gradual but steady process of liberalization would have required consensus among different interested groups and a mature institutional framework capable of limiting the incumbent government's ability to discretionally introduce major shifts in trade policy and benefit some groups at the expenses of others. Argentina lacked such institutions and as a result trade liberalization occurred abruptly, without consensus and too late.

\section{A simple model}

In this section, we introduce a simple model that we use to articulate the analytical discussion in the next section. We use a model with two tradable goods and one non-tradable good. The tradable goods are labeled as agricultural (a) and manufactured $(\mathrm{m})$. The agricultural good is produced in the primary sector, using land and capital, while the manufactured good is produced in the secondary sector, using labor and capital. The non-tradable good (n) is labeled as a service and is produced using labor only. The economy is endowed with $K$ units of capital, $T$ units of land and $L$ units of labor.

The tradable goods are produced using the following Cobb-Douglas production functions: ${ }^{1}$

$$
\begin{gathered}
Y_{\mathrm{a}}=A T^{1-\alpha} K_{\mathrm{a}}^{\alpha}, \\
Y_{\mathrm{m}}=M L_{\mathrm{m}}^{1-\beta} K_{\mathrm{m}}^{\beta} .
\end{gathered}
$$

The non-tradable good is produced with the following linear technology:

$$
Y_{\mathrm{n}}=L_{\mathrm{n}}
$$

where $Y_{i}$ is the total output of good $i$ and $K_{i}\left(L_{i}\right)$ is the amount of capital (labor) employed in sector $i \in\{a, m, n\} . A(M)$ is the total factor productivity in the primary (secondary) sector. We assume that capital is used more intensively in the secondary sector: $0 \leq \alpha \leq \beta \leq 1$. We also assume that there are many competitive firms in each sector, which allows us to cast the model in terms of a representative firm of the sector that behaves competitively.

\footnotetext{
1 The parameters $\mathrm{A}$ and $\mathrm{M}$ in the production functions of the tradable goods can be interpreted as neutral technological shocks. However, if the production function were instead to include an additional imported input with a low elasticity of substitution, then an increase in the price of that input could be interpreted as a change in $\mathrm{A}$ and/or $\mathrm{M}$.
} 
Since our focus is on the functional distribution of income, we consider three types of agents: workers, endowed with one unit of labor; landowners, endowed with equal shares of the total rewards to land; and capitalists, endowed with equal shares of total capital. Agents consume the three goods $(a, m, n)$, for which they have identical preferences as represented by a Cobb-Douglas utility function: ${ }^{2}$

$$
U_{j}=\phi_{\mathrm{a}} \ln c_{\mathrm{a} j}+\phi_{\mathrm{m}} \ln c_{\mathrm{m} j}+\left(1-\phi_{\mathrm{a}}-\phi_{\mathrm{m}}\right) \ln c_{\mathrm{n} j},
$$

where $c_{i j}$ is the consumption by agent $j$ of $\operatorname{good} i$. We will use $C_{i}$ to denote aggregate consumption for good $i$.

We assume that the Argentine economy is a price-taker in world markets. Therefore, the international prices for the agricultural $\operatorname{good} p_{\mathrm{a}}$ and the manufactured good $p_{\mathrm{m}}$ are considered exogenous. The terms of trade are denoted by $\pi=p_{\mathrm{a}} / p_{\mathrm{m}}$, i.e., the relative price of exports over imports. We also assume the absence of any international capital markets; therefore, trade should be balanced in equilibrium.

The government intervenes in the economy by taxing trade. Without loss of generality, we assume that the government introduces an ad valorem tax on exports at rate $\tau$. We confine our attention to taxes on exports of the primary good. Since the equilibrium depends on relative prices, the effect of any tax on imports can be replicated by a tax on exports (Lerner symmetry result). Because we are interested in Argentina, which is a country with comparative advantages in the primary sector, we will not fully develop the case in which the pattern of trade reverses. If the economy reverses its pattern of trade, we assume that export taxes (on the manufactured good) are zero. The economic agents take the export tax, $\tau$, as given. Unless the country is in autarky, domestic prices are given by $p_{\mathrm{a}}^{d}=p_{\mathrm{a}}(1-\tau)$ and $p_{\mathrm{m}}^{d}=p_{\mathrm{m}}$, where the nominal exchange rate is normalized to 1 . We assume that the government reinjects the tax proceeds into the economy via lump-sum transfers to agents.

\subsection{The long-run equilibrium}

In the long-run equilibrium, firms hire capital and labor competitively and produce according to their production functions, while consumers sell their endowments to the firms and buy the produced goods with the proceeds. In the appendix, we solve for the long-run equilibrium of this economy (see Sect. 7.1). Here, we will highlight our results.

It will be useful, for our purposes, to consider the preferences parameters $\left(\phi_{i}\right)$, the technological parameters $(\alpha$ and $\beta$ ) and the endowments of the economy as being fixed. We will focus on the effects of changes in the terms of trade $(\pi)$ and export duties $(\tau)$. As shown in the appendix, there are four types of long-run equilibria:

- Specialization: the country produces only in the primary and tertiary sectors; it imports the manufactured good and exports the agricultural good.

\footnotetext{
${ }^{2}$ Homogeneity of degree one allows us to ignore distributional issues in computing the steady state of the economy and studying its equilibrium properties. Unitary elasticity of substitution also simplifies the computation of the steady state.
} 
- Diversification and trade: the country produces in the three sectors; it imports the manufactured good and exports the agricultural good.

- Autarky: the country produces in the three sectors; there is no trade.

- Diversification and reversal of the pattern of trade: the country produces in the three sectors; it imports the agricultural good and exports the manufactured good.

Each pair $(\pi, \tau)$ is associated with one and only one of these equilibria; therefore, under the assumptions made, we can represent the areas or regions that correspond to each of these types of long-run equilibria in the $(\pi, \tau)$ plane:

Notice that, for a given tax rate $\tau$, as the terms of trade worsen ( $\pi$ decreases), the economy moves from specialization to diversification and trade, to autarky and, finally, to a reversal of the patterns of trade. For higher levels of taxes $\tau$, the autarky region is larger.

Consider the share of capital employed in the secondary sector: $\kappa=K_{\mathrm{m}}$ / $\left(K_{\mathrm{m}}+K_{\mathrm{a}}\right)$. This is a measure of industrialization that will be useful in our discussion about preferences for protectionism. Figure 2 shows how this share varies in the long-run equilibrium for different configurations of terms of trade and taxes. A figure for $\lambda=L_{\mathrm{m}} /\left(L_{\mathrm{m}}+L_{\mathrm{a}}\right)$ would look similar.

Notice that the specialization region in Fig. 1 coincides with the region where $\kappa$ equals zero in Fig. 2. Under specialization and trade, capital and labor employment in the secondary sector are zero.

In the autarky region, the tax rate is set high enough so that the country will not trade with the rest of the world; consequently, changes in $\pi$ or $\tau$ will have no marginal effect on the resulting allocation of resources in the economy. For any point in the region, the factor allocation is the autarky allocation, which we denote as $\kappa_{\text {aut }}$ and $\lambda_{\text {aut }}$ (see Sect. 7.1.1 in the appendix). The autarky region in Fig. 1 coincides with the region with $\kappa=\kappa_{\text {aut }}$ in Fig. 2.

In the diversification and trade region, the manufacturing sector employs capital and labor. As we move upward and to the left within this region, both $\kappa$ and $\lambda$ increase from zero, as in the frontier with the specialization and trade region, up to $\kappa_{\text {aut }}$ and $\lambda_{\text {aut }}$ in the autarky region. The diversification and trade region in Fig. 1 coincides with the region where $\kappa$ is increasing in Fig. 2.

Finally, in the reversal of patterns of trade region, the tax rate on agricultural exports has no effect on the real economy. As $\pi$ decreases, the secondary sector grows and employs more resources. The reversal region in Fig. 1 coincides with the leftmost region in Fig. 2. As the terms of trade worsen, the share of capital in the secondary sector approaches one; however, the share of labor, $\lambda$, converges toward an upper bound that is less than one, since some workers are always employed in the tertiary sector.

It seems appropriate to make two remarks about our model and its usefulness in analyzing the Argentine economy. First, we have simplified the analysis to two tradable sectors. Therefore, our model does not allow for an equilibrium in which some manufactures are exported while others are imported. This is due to the assumption that manufactures are a homogeneous good. A careful interpretation of our model is nonetheless helpful in building our narrative of Argentina's economic 


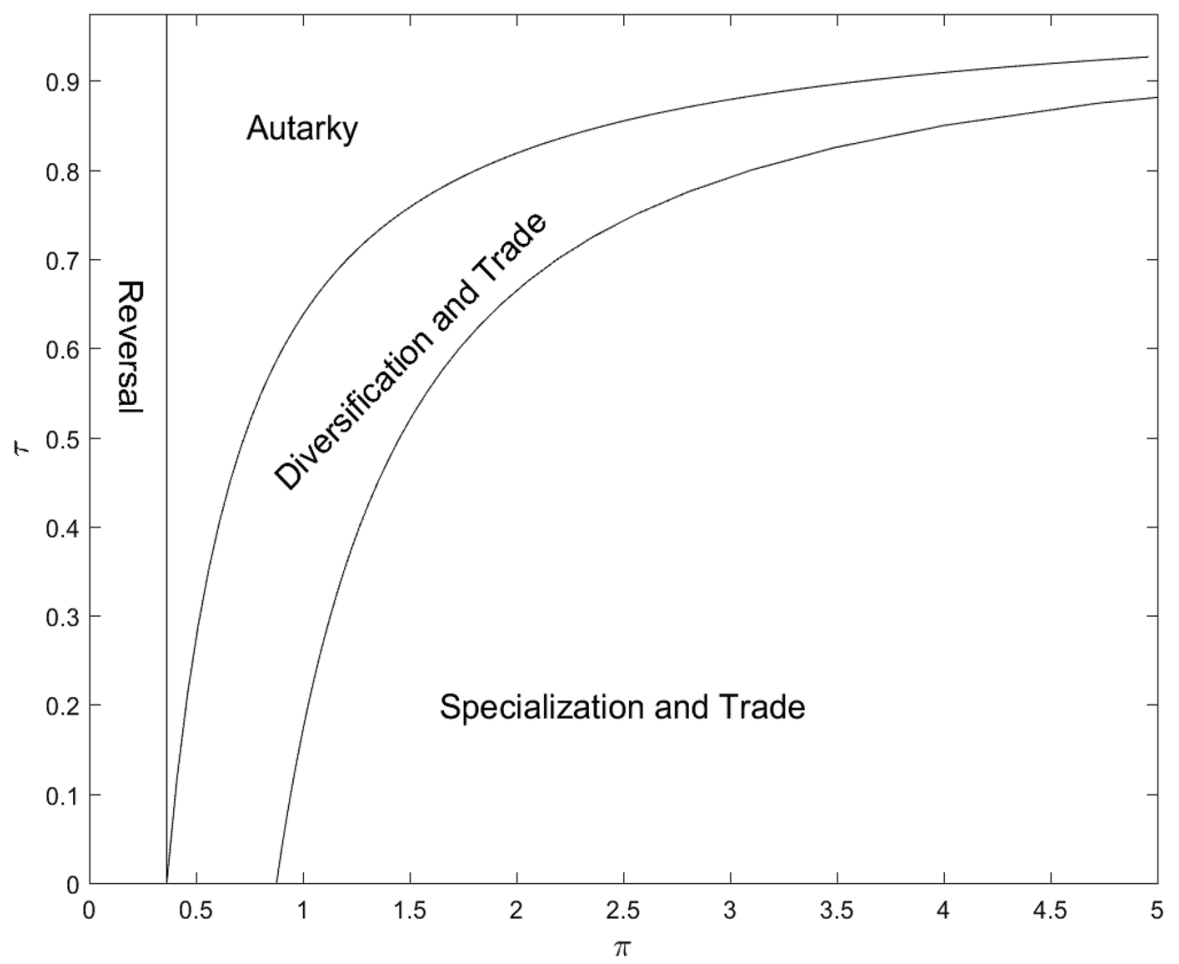

Fig. 1 The long run: four regions

history. The manufacturing sector should be interpreted as comprising the activities that compete with imports, the primary sector as the set of activities oriented toward the international market and the tertiary sector as the services and manufactures that are naturally protected from external competition. Thus, our model assumes that exportable activities are intensive in capital and land, import-competing manufactures in labor and capital, and non-tradables in labor.

Second, we should interpret the autarky equilibrium as representing a situation in which the economy has exhausted its possibilities of import substitution, rather than as an actual autarkic situation. During the period under consideration, Argentina was never in actual autarky; however, it took its import-substitution strategy almost all the way to its technological limit. Of course, there were some inputs that had to be imported because it was simply not feasible to produce them domestically. ${ }^{3}$

\footnotetext{
${ }^{3}$ We can reinterpret our model to accommodate an imported input. For a linearly homogeneous CobbDouglas production function on $K, L$ and the imported input $F$, we can write the value-added function $\mathrm{VA}=Y-p_{\mathrm{f}} F$. If $F$ is chosen optimally for a given $p_{\mathrm{f}}, K$, and $L$, then the value-added function is also a linearly homogenous Cobb-Douglas on $K$ and $L$. Our production functions should be reinterpreted as value-added functions. An increase in the international price of the imported input can be reinterpreted as a negative productivity shock in the sector where the input is employed.
} 


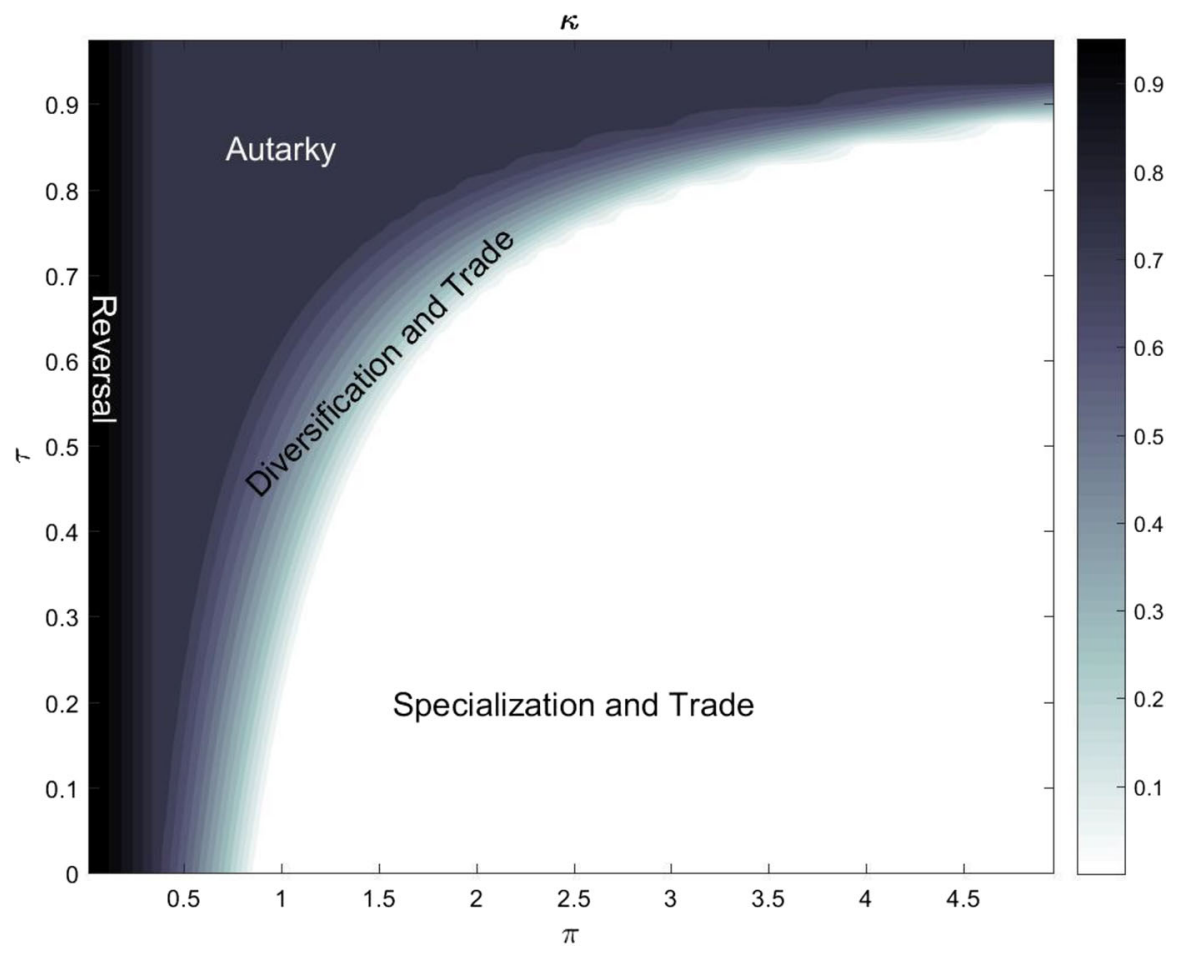

Fig. 2 The long-run equilibrium, $\kappa$

\subsection{Political economy}

Our assumption that each agent owns a single type of input allows us to group agents according to the input they own and the industry where they are employed. As we show below, the tax rate $\tau$ affects the real remuneration of each of these groups in a different way. Some groups will gain from an increase in protectionism (higher $\tau$ ), while others will lose. Thus, there is a distributional conflict around protectionism.

Notice that no conflict would arise in an economy where each agent owns the same bundle of inputs. Yet, agents endowed with different resources have conflicting interests. The essence of the rivalry between proponents of free trade and advocates of protectionism lies in the assumption that each agent can be identified with one of the socioeconomic groups based on the inputs that the agent owns and the industry in which the agent is employed.

The reader will recall that we have assumed that tax revenues are distributed in lump-sum transfers to agents; thus, the agents' attitudes will also depend on the share of total tax revenues that each one of them expects to receive. Since we do not specify who the recipients of the lump-sum transfers are, we should bear in mind that, even if a group's real remuneration is reduced by an increase in export taxes, its overall utility might increase if the group receives a disproportionately bigger 
share of tax revenues. We should also bear in mind that, given the first welfare theorem, it is impossible to put each and every agent in a better off position by increasing the tax rate and redistributing the revenues.

In analyzing the effect of changes of $\tau$ on each group's welfare, we consider the short-, medium- and long-run time horizons. In the short run, no reallocation of factors takes place. In the medium run, only labor is allowed to move between the secondary and tertiary sectors. In the long run, all factors can be reallocated, and the economy fully adjusts to its new long-run equilibrium.

In Appendix 1 (Sect. 7.2.1), we show that the diversification and trade region is particularly prone to distributional conflict. This is because, in the other regions, either all interests are aligned (under specialization) or a marginal change in the export tax rate has no real consequences (under reversal of the pattern of trade and autarky). Therefore, we will focus on pairs $(\pi, \tau)$ such that the economy will be in the diversification and trade region.

In the short run, protectionist policies will benefit owners of factors employed in the secondary sector and will harm those employed in the primary and tertiary sectors. Since the proportion of factors employed in the secondary sector increases as we move upward and toward the left in the diversification and trade region, protectionist policies have more short-run support as we move closer to the autarky region and less support as we move closer to the specialization area (see Proposition 3 in Appendix 1).

In the medium run, landlords and capitalists with investments in the primary sector will oppose protectionism, while capitalists with investments in the secondary sector will support it. Workers will now have a homogenous attitude toward $\tau$; either all workers will prefer protectionism or all of them will oppose it. We show that the pairs of $(\pi, \tau)$ at which workers switch from opposing protectionist policies to supporting them lies in the diversification and trade region (see Proposition 5 in Appendix 1) (Fig. 3).

In the long run, landlords will always oppose protectionist policies and will benefit from improvements in terms of trade (Proposition 6, Appendix 1). One of our key results is that workers will also prefer a zero tax rate if $\pi$ is sufficiently high (Proposition 7, Appendix 1). In this case, workers prefer to be employed in the tertiary sector where they can take advantage of the high level of national income induced by high terms of trade. The result for capitalists is similar; for a sufficiently high $\pi$, farsighted capitalists will also support free trade policies.

The key insight that we want to convey here is that agents will support or oppose policies according to their source of income and their relevant time horizon. In the diversification and trade region, agents' attitudes toward protectionism exhibit an interesting pattern. Landlords oppose them in all cases; capitalists employed in the manufacturing sector support them both in the short and medium terms. ${ }^{4}$ Who

\footnotetext{
${ }^{4}$ We will assume that capitalists are not farsighted. We are careful to draw the distinction between different time horizons in view of the fact that capital is not perfectly mobile across sectors. If we were to assume that capital is, in fact, not mobile at all and that capital reallocation occurs only through a process in which depreciated capital in one sector is not replaced while the other sector has a positive net rate of investment, then it would make perfect sense to assume that capitalists whose capital is already locked into one of the two sectors will only care about the short and medium terms.
} 


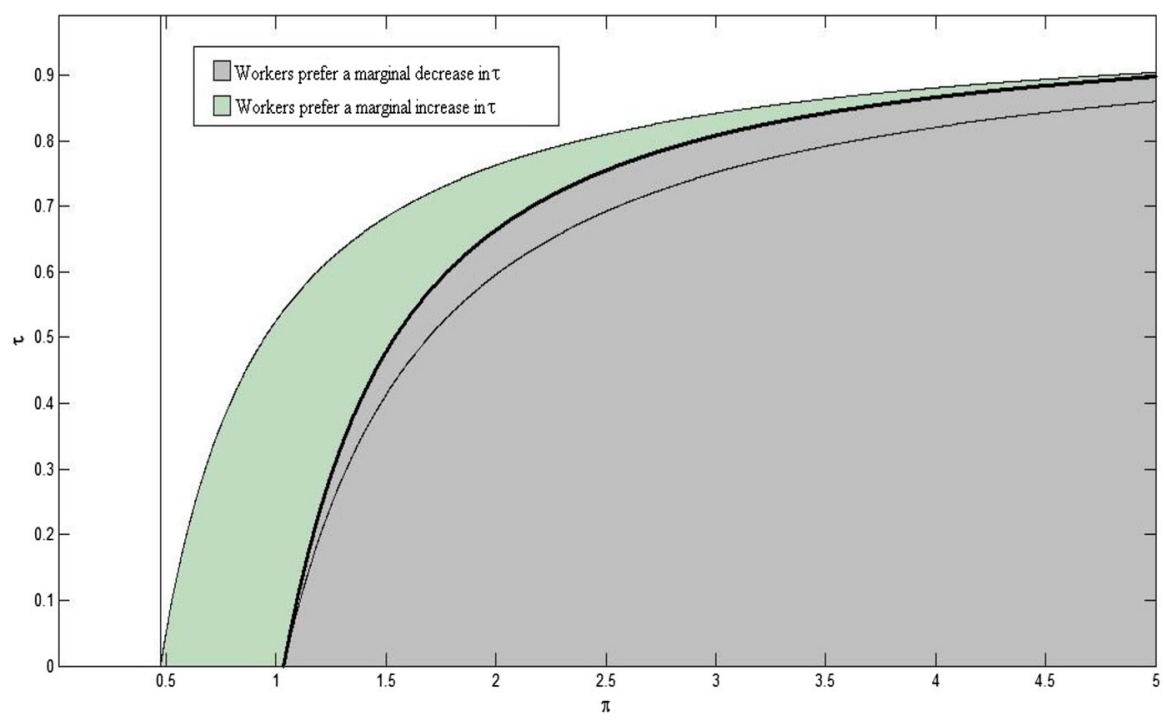

Fig. 3 Medium-run preferences over $\tau$

prevails in this struggle depends on several factors that are beyond the scope of this paper; however, our analytical model gives us some mileage in answering this question. It seems fairly reasonable that the size of the capitalist faction that supports protectionism will be positively correlated with the likelihood of these policies being enacted. Moreover, in a democracy, workers could be the pivotal faction that shifts the balance of power.

Clearly, as we move upward and to the left in the diversification and trade region, protectionist policies will enjoy wider support. As we move in this direction, both workers and capitalists will be more likely to advocate these policies. In the short run, there will be more workers and capitalists employed in the manufacturing sector. In the medium run, workers as a whole group are also more likely to prefer taxation. $^{5}$

This model can also generate endogenous pressure for the enactment of free trade policies in a protected economy that experiences favorable terms of trade or high levels of productivity in the primary sector. As $\pi$ grows, farsighted workers will stand to benefit greatly from free trade policies. Landlords' remuneration under free trade is greater when $\pi$ is large, and they will therefore support these policies more actively. Consequently, if the economy is trapped in the autarky equilibrium, higher $\pi$ will intensify the distributional conflict because those who want to challenge the status quo have more incentives to do so.

\footnotetext{
5 There is a significant difference between the outcomes in the short and medium terms. In the medium run, workers are a homogeneous group and, when they change their preferences toward protectionism, they do so as a group. In the short run, only those employed in the secondary sector will support protectionist policies; therefore, anti-trade policies gain adherents gradually as $\lambda$ increases.
} 


\subsection{Path-dependent import-substitution policies}

We will now discuss how, starting from a situation of specialization, a significant and exogenous worsening of the terms of trade may lead to an incipient industrialization process, change the "political equilibrium" and lead to the introduction of an import-substitution policy. Interestingly enough for our case study, even if the terms of trade were to later rebound to the previous level at which the economy operated under specialization, new endogenous political forces may have developed that prevent the economy from returning to its initial stance. As in the cases of path dependence discussed in the literature on inefficient institutions (see, among others, North 1990), there are self-reinforcing mechanisms for the persistence of import-substitution policies.

Suppose that the economy is specialized in the primary sector. In that case, the preferences of all agents in the economy are aligned; they all agree on a zero export tax rate. Naturally, this does not mean that they agree on the level of redistribution by other means such as an income tax, but we are abstracting from the analysis of these issues here. Suppose that the terms of trade worsen significantly and that the country naturally initiates an incipient industrialization process, i.e., the economy moves into diversification and trade. Initially, protectionist policies will lack support, since most of the capital is still employed in the primary sector and most workers produce services. If workers take into account the medium-run prospects, they may favor an increase in $\tau$; however, for most of them, it is likely that the shortrun costs of a tax increase would outweigh the medium-run benefits.

As the process of industrialization deepens, either because of a further deterioration in the terms of trade or because of capital flows from the primary to the secondary sector, the short- and medium-run support for protectionist policies increases and eventually these policies may be implemented. Protectionism tends to be self-reinforcing, since now more capital and labor will flow to the secondary sector. New waves of demand for protectionism drive the economy toward autarky, which might be characterized as an import-substitution strategy. Notice, however, that for this to happen, either the economy has to have a high level of capital-i.e., to be rich enough - to transfer capital from the primary sector to the manufacturing sector, and the shock has to be sufficiently long-lasting to allow the economy to accumulate enough capital in the manufacturing sector to give rise to a protectionist coalition.

Suppose now that, once the economy is industrialized and the import-substitution strategy has driven the economy close to autarky, the terms of trade improve. In the short run, this harms all the agents who have switched to the secondary sector. However, if these agents hold political power, they will not allow capital to flow back to the primary sector; instead, they will increase the export tax. If the tax is increased to levels that ensure autarky, the improvement in the terms of trade will not have any real effect. The economy will be trapped in a situation where every improvement in the terms of trade will be neutralized and nobody will gain (or lose) from it.

If the terms of trade improve, the distributional conflict becomes more intense. Workers may benefit from a reduction in the tax rate in the long run. Moreover, 
landlords' incentive to exert influence in the political arena will increase, because the benefit of reducing the level of protectionism increases with the terms of trade. They will be opposed by industrial capitalists and shortsighted workers who benefit from protectionism. This distributional conflict may grow in intensity, destabilizing the political equilibrium and, depending on how the conflict is resolved, spurring liberalization. Similarly, the distributional conflict will also become more severe if the productivity in the primary sector increases.

The next subsection deals with other forces that may give rise to trade liberalization, not through increased distributional conflict, but by weakening the protectionist political coalition of workers-capitalists.

\subsection{Forces leading to trade liberalization}

Events that reduce the proportion of workers and capital in the manufacturing sector will weaken the coalition that supports protectionist policies. We have discussed how an increase in the price or productivity of the agricultural sector may generate enough distributional conflict to prompt the formation of a coalition of landlords and longsighted workers that supports liberalization. In this subsection, we show what other kinds of events can shift employment and capital allocation when the economy has traveled far enough down the road of protectionism.

In our basic model, protectionism will lead the economy somewhere near autarky. The assumptions of Cobb-Douglas preferences and technology imply that the shares of labor and capital $(\lambda$ and $\kappa$ ) in autarky depend only on the CobbDouglas shares $\left(\alpha, \beta, \phi_{\mathrm{m}}\right.$ and $\left.\phi_{\mathrm{a}}\right)$ and not on factor endowments or productivity (see Sect. 7.1.1 in Appendix 1). This will not be the case if we relax the Cobb-Douglas assumption. We can first relax the assumption of unitary elasticity of substitution in preferences and technology. We can go even further and relax the homotheticity assumption. We note that, if preferences are elastic but technologies are not, the share of workers employed in the secondary sector decreases with both population growth and productivity in the primary sector.

Finally, we conjecture that labor unions that were created or empowered to maintain and support protectionist policies also generated frictions in the labor market that ended up depriving them of their most vital input: unionized workers.

\subsubsection{Relaxing the Cobb-Douglas assumption}

In this section, we analyze how shocks to factor endowments and productivity can change the factor allocation of an economy in autarky. As shown in Sect. 7.1.1 in the Appendix, if preferences and technology are Cobb-Douglas, then the shares of labor and capital $(\lambda$ and $\kappa)$ in autarky will depend only on the parameters $\left(\alpha, \beta, \phi_{\mathrm{m}}\right.$ and $\phi_{\mathrm{a}}$ ), rather than on factor endowments or productivity. However, under more general preferences or technologies, capital and labor shares will depend on productivity and endowments.

In Sect. 7.3 in the appendix, we show how changes in endowments or productivity can shift the allocation of labor and capital if we relax the assumption of unitary elasticity of substitution. We could comment on many different shocks 
that, together with some assumptions about the elasticities of substitution (EoS), would result in a smaller share of workers employed in the manufacturing sector (lower $\lambda$ ); however, we will focus on just two shocks: population growth and technological improvements in the agricultural sector.

Population growth will decrease $\lambda$ if the EoS in consumption is greater than the EoS in the production of manufactures. The intuition is that an increase in the number of workers will push wages down. As a result, both manufactures and services will become cheaper. However, the percentage fall in price will be sharper in services (i.e., services will become cheaper relative to manufactures) because services employ only labor. The increase in the demand for services will be directly related to consumers' elasticity of substitution. Because labor becomes cheaper, the manufacturing sector will become more labor intensive. The increase in demand for labor in the secondary sector will be related to the elasticity of factor substitution. If consumers' preferences exhibit more elasticity of substitution than manufacturing firms' technology, the share of workers employed in the service sector will increase. A similar argument shows that the shift in the share of capital, $\kappa$, will have an opposite sign from the shift in $\lambda$. Therefore, under these circumstances, we may expect to see that, as population grows, $\lambda$ decreases and $\kappa$ increases.

Higher productivity in the agricultural sector will reduce $\lambda$ if the $\operatorname{EoS}$ in preferences is greater than 1 and greater than the EoS in the technology of manufactures. ${ }^{6}$ Moreover, the share of capital, $\kappa$, will decrease if the EoS in preferences is greater than 1 . The intuition is that an increase in productivity in the agricultural sector will depress the autarky price of the primary good and increase the return of capital. High substitution elasticity in consumption implies that consumers will increase the share of primary goods in their bundles and that capital will move from the secondary to the primary sector. Low elasticity of substitution in the manufacturing sector implies that the marginal productivity of labor in that sector will decrease rapidly as a consequence of decapitalization; therefore, labor will shift to the tertiary sector.

Alternatively, if preferences and technology are not homothetic, then it is possible to obtain decreasing $\lambda$ and $\kappa$ following exogenous shocks if they change the total income of the economy or total production of a particular good. For example, if the manufacturing sector becomes more capital intensive, then the autarky equilibrium will result in a smaller $\lambda$ and a larger $\kappa$. Similarly, if preferences shift toward services as income grows, then neutral technological improvements or increases in all endowments will reduce $\lambda$ as more workers become employed in the service sector. Moreover, if the share of total income represented by food expenditures tends to decrease and food is produced in the primary sector, then the primary sector will tend to shrink under autarky (i.e., $\kappa$ increases). More importantly, since the primary good has less weight in the consumption bundle, the impact of trade liberalization on workers and industrial capitalists is less harmful.

\footnotetext{
${ }^{6}$ It will also reduce $\lambda$ if the EoS in consumption is less than 1 and less than the EoS in the production of manufactures.
} 


\subsubsection{Trade and unions}

We have discussed how protectionist policies shift labor and capital employment to the secondary sector, which reinforces the political demand for protectionist policies. So far, we have abstracted from the institutions and organizations that might emerge to represent these demands. As we will argue later, labor unions were organized and empowered during the Peronist period and were key actors during the following 40 years. Labor unions' most visible role was not lobbying for protectionism, but intervening in the wage-setting and employment decisions of manufacturing firms to keep real wages high and avoid layoffs. In this section, we will explain why, if the number of workers in the economy is increasing, unions' zeal to prevent wage declines will lead to an increase in the share of workers employed in the service sector and to their ultimate loss of political power.

Labor unions can influence wages in two basic ways. First, by restricting the access of workers to the manufacturing sector (e.g., enforcing closed-shop agreements), they can prevent wage equalization between the secondary and tertiary sectors and maintain a positive industrial wage premium in the medium and long run. Second, through aggressive collective bargaining, they can obtain a higher share of total remuneration and reduce the return to capital in the sector in the medium run. In an environment where the relative supply of workers is increasing, unions will have to rely on some of these interventions if they are to keep real wages from falling.

If labor unions effectively restrict access to the manufacturing sector, the service sector will absorb a disproportionately high number of new workers in the medium run and long run. This will result in a growing share of workers employed in the service sector being opposed to the labor unions; they will be against both restricted access and protectionist policies.

On the other hand, if labor unions can use their market power to set wages above the value of the marginal product of labor, then the remuneration of capital in unionized activities will decrease. In the long run, capital will flow to alternative uses, such as agriculture or non-unionized manufacturing activities. Decapitalized, unionized manufacturing activities will not hire new employers and, as a result, union membership will decline in relative terms.

In both of the cases reviewed above, unions' objectives of keeping wages high and avoiding layoffs of union members run counter to their long-run survival in a context where population growth outpaces capital accumulation.

\subsection{Lessons from the model}

The key result of our model is the finding that protectionist policies are pathdependent. A land-rich economy that is well integrated into world markets may embark upon an industrialization process in response to poor terms of trade, especially if the new prices are not a transient shock. This incipient industrialization process is possible if the economy has enough capital-i.e., if it is rich enough—and labor; otherwise, the secondary sector will not be profitable and the economy will not be able to cushion the negative terms-of-trade shock. 
Starting from the onset of the industrialization process, capitalists and workers recently employed in the industrial sector have incentives to lodge demands for protectionism. As the process advances, the political power of these groups grows and, eventually, their demands may be met. As a consequence, the industrial sector receives a new boost at the expense of the primary and tertiary sectors, and the economy gradually becomes closed to world markets. Moreover, the political coalition supporting protectionism gains power. As a result, anti-trade policies become entrenched and the economy moves closer to autarky. Even if the conditions that gave rise to the endogenous industrialization subside, the economy remains closed, since the alliance of capitalist and workers retains its power.

However, the anti-trade alliance is not unbreakable. Secular trends in labor supply, frictions between workers and capitalists or a strong improvement in terms of trade can push the economy back into a free trade equilibrium:

Under more general preferences and technology, population growth and higher productivity in the primary sector can shift the factor allocation and lead to increased demands for free trade. In both cases, under some conditions, a greater share of workers will be employed in the service sector. Therefore, more workers will support liberalization.

Similarly, if services gain in importance in the consumption bundle, more workers will be employed in the tertiary sector. As a result, there will be greater support for liberalization. Moreover, even the owners of inputs employed in the secondary sector will have weaker incentives to support protectionism if this shift toward services occurs at the expense of the consumption of the exportable good.

Once the economy is near autarky, capitalists and workers will not be able to use their coalition's political power to pursue further industrialization. Besides, they will be extremely vulnerable to negative shocks in industrial productivity (e.g., an increase in the price of a non-modeled importable input). Under these circumstances, unions may be tempted to use their power against capitalists, thereby weakening their alliance. We have discussed how unions, in their zeal to keep wages from falling in the short run, may introduce distortions that reduce their power in the long run.

Finally, an improvement in terms of trade or an increase in agricultural productivity increases the incentives for landlords to intervene in the political process. The economy will be able to escape the anti-trade trap if landlords are successful in challenging the coalition of industrial workers and capitalists.

\section{Analytical narrative}

Argentina did relatively well when it was integrated with world markets. Why, then, did it remain under autarky for approximately 60 years? We will now use the model outlined in the previous section to articulate an analytical narrative concerning the political economy of autarky during the twentieth century in Argentina. 


\subsection{The Belle Époque}

In 1860, Argentina was a fairly empty land. As in the rest of Latin America, the pace and characteristics of Argentine expansion were fundamentally determined by the success with which some of its regions became exporters of primary products (see Cortés-Conde 1979). The period from 1870 to 1914 was one of free trade and market integration and during this period the country benefited from its marked comparative advantage in the primary sector due to its vast amount of highly fertile land (O'Rourke and Williamson 1999). The dramatic decline in transport costs during the late nineteenth century led to a trade boom and commodity price convergence internationally. In Argentina, the scarcity of labor and abundance of land, relative to Europe, induced a high marginal product of labor. The wage differential between Argentina and some European countries attracted a colossal flow of overseas immigrants, who came to constitute the majority of Argentina's labor force. A similar process also triggered a massive flow of capital into the country (see Cortés-Conde 1979).

During the second half of the ninetieth century, a large proportion of Argentine land was settled and divided up into latifundia (Adelman 1994). The sharp increase in the availability of land spurred an expansion in livestock raising, primarily because it was a non-labor-intensive activity that could be launched at a time when labor was a scarce resource.

With the pattern of land ownership determined by political history, and with prices of exports, imports and capital set by international markets, total rents depended on the labor supply. Therefore, immigration policy became the critical policy variable under the control of the government (Díaz-Alejandro 1984). Not surprisingly, the Argentine elite chose to promote immigration. The expansion of agricultural activities and a pro-immigration policy paved the way for a very substantial increase in the urban population, especially in Buenos Aires. In addition to its administrative functions as the capital of the country, this city developed an increasingly large and sophisticated service sector.

The export-oriented growth made possible by an expanding international market raised per capita income in a sustained and substantial way. Indeed, the growth process was closely related to successive booms in the exports of land-intensive commodities, with land having a very low opportunity cost. The economic usefulness of the pampas was not discovered overnight, as an oil deposit might be, but instead arose as the result of the combination of a growing European need for primary goods, technological progress in transport and an increasing interest on the part of Argentine policymakers in promoting exports, foreign investment and immigration. By the beginning of the twentieth century, however, the Argentine growth process had become less dependent on the discovery of new resource-based export commodities and on the performance of any one export. It still relied heavily, however, on a steady expansion of exports based on the growth of the world economy and on the completion of the adjustment by which primary production was being transferred from Europe to more recently settled countries (see DíazAlejandro 1970). 
The early manufacturing sector was closely linked to the primary sector and supplied the domestic market with products that were naturally protected from external competition, (e.g., wine, meat and flour). There also was a smaller industrial sector that competed with imports (e.g., clothes, cigarettes, perfumes). These industries were granted some degree of protection after the passage of the Customs Act of 1876. However, the level and extent of protectionism were rather limited compared to what was yet to come (Gómez-Galvarriato and Williamson 2009). First, the main goal of these customs duties was to obtain revenues for the government, which was a widely accepted practice in Latin America at the time (see Brambilla et al. in this volume). Second, the protected activities accounted for a small share of total economic activity and, to a large extent, the policy was geared toward protecting regional products as a means of preserving the federalist model adopted by the country. Thus, this specific departure from free trade can be more accurately interpreted as a means of securing revenues and of sustaining a political order that, on the whole, was pro-export oriented.

Thus, in our view, the period from 1870 to 1914 was one of specialization in production, with the country specializing in the production of primary goods, importing manufactured goods and employing its workers mainly in the primary sector and the services industry. This was therefore a period in which the political views of the majority of economic agents were aligned against protectionist policies.

\subsection{Globalization backlash}

It is not clear whether Argentina could have sustained its fast pace of growth under specialization (see Llach in this volume) if the world had remained widely integrated, as it was during the Belle Époque. However, there is no reason why it should not have diversified its production and exports of agricultural and manufactured goods under a policy of free trade. Had the terms of trade remained favorable for Argentina, even if the productivity of the primary sector had not kept increasing rapidly, some manufacturing sectors would have eventually become competitive and taken off. What is more, if the economy had continued to expand, it would have begun to meet an increasing (but previously inexistent) domestic demand for many manufactured goods, thereby encouraging their domestic production, particularly in view of the existence of natural barriers. The same reasoning applies to services (see Galiani et al. 2008).

Instead, the country's fortune took a sharp turn for the worse in the 1930s. World trade collapsed after the Great Depression. The 1932 Ottawa Conference marked the end of multilateralism in international trade. Great Britain, Argentina's foremost trading partner, shifted its trade to members of the Commonwealth. A protectionist pandemic spread throughout the world. As a consequence, the ratio of world trade (export plus imports) to GDP declined from 22\% in 1913 to $9 \%$ in the 1930 s. Though there was a recovery toward the end of the decade, international trade was again disrupted during the Second World War, when it was geared toward war requirements. Trade opportunities did not start to improve until after the Second World War under the Bretton Woods system and with the signing of the General 
Agreement on Tariffs and Trade (GATT). Then world trade began to recover and, by 1950 , it had surpassed pre-war levels, mostly thanks to the growth of transAtlantic and intra-European trade. ${ }^{7}$ There is a consensus that, after the Second World War, a second globalization era began (see, among others, Baldwin and Martin 1999; Williamson 2002). Nevertheless, the move toward multilateralism was gradual and was not achieved, for all practical purposes, until the 1990s (see Brambilla et al. in this volume for a fuller discussion of these issues).

The breakdown of the economic order was transmitted to Latin America first of all through a sharp change in relative prices: dollar export prices collapsed more steeply than dollar import prices. According to Clemens and Williamson (2002), the magnitude of the decline was around 30\% for Asia and the Middle East and $40 \%$ for Latin America. This decline in the terms of trade was used as a strong argument in support of the move of the developing world toward autarky in the 1940s and 1950s, within the context of a highly interventionist industrialization strategy.

In Argentina, the terms of trade deteriorated considerably even before the collapse of the international economic order in the early 1930s (see Fig. 4). During the 1920 s, on average, the terms of trade were approximately $30 \%$ below the preFirst-World-War level of 1913. Such a shock alone merits the label of a reverse of fortune. For a country with a ratio of exports to GNP of one-to-three, a $30 \%$ deterioration in the terms of trade represents a loss in real income of about onetenth, assuming no change in physical output. The 1930s show some recovery in relative prices, which still were, on average, about 16\% below their 1913 level. This reversal of fortune, with some pronounced fluctuations, continued throughout the rest of the twentieth century. Just to put this into perspective, the average terms of trade for the period 1930-1999 was $20 \%$ below the average relative prices for the period 1890-1913. Nevertheless, in recent years the terms of trade have improved substantially.

The protectionist measures enacted by most countries in the world and the increased risk of sending goods overseas during wartime reduced trade opportunities beyond what would be expected as a result of the terms of trade. To sum up, in the late ninetieth century, Argentina had highly auspicious opportunities to trade with the rest of the world: favorable terms of trade, peace and the application of free trade policies by its trading partners. The terms of trade did not start to decline until early in the twentieth century and were then followed by war and protectionist policies.

\subsection{Endogenous industrialization}

The deterioration in the terms of trade during the 1920s severely damaged the economy. At the same time that the profitability of the primary sector was plummeting because of low export prices, opportunities in the secondary sector

\footnotetext{
7 After successive rounds of negotiations, substantial tariff reductions were put into practice, mainly for industrial products. Unfortunately for Argentina, distortions in the trade of agriculture products remained relatively high. In the USA, subsidies to American farmers date from the Great Depression, whereas, in Europe, protectionism in agriculture emerged in response to the food shortages that the continent suffered during the Second World War.
} 


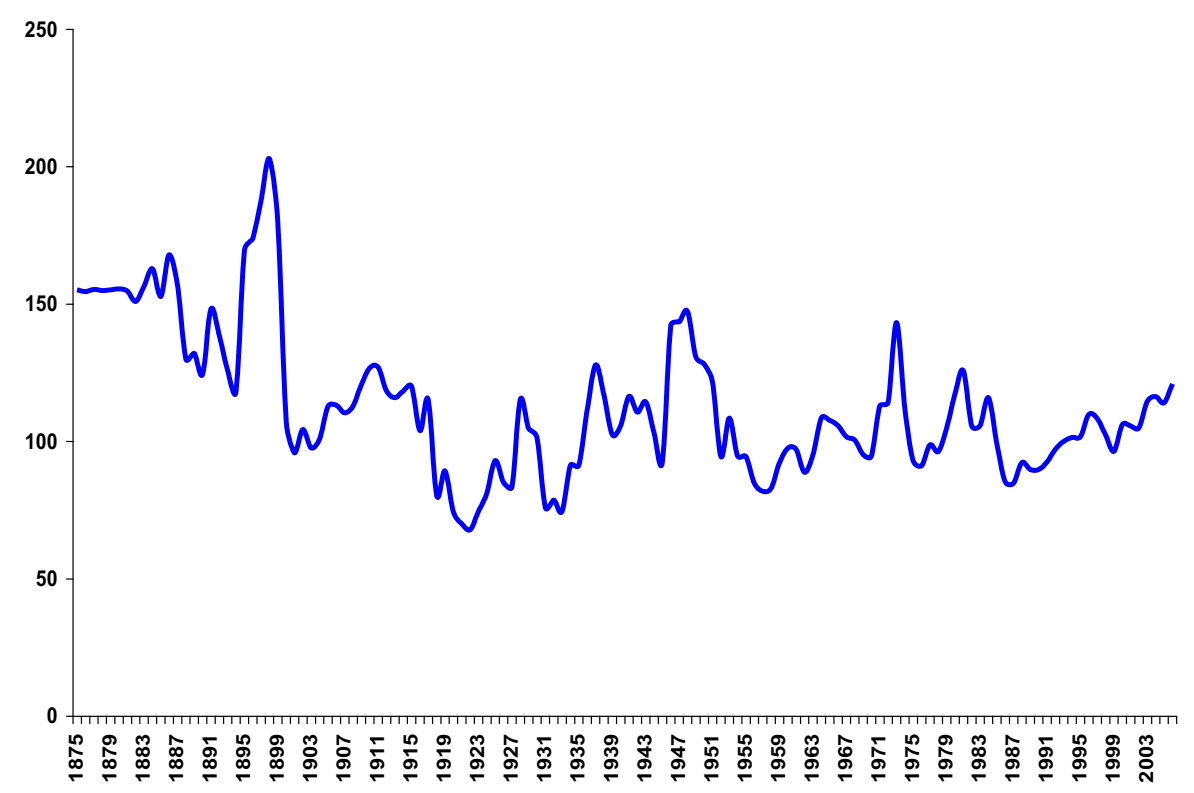

Fig. 4 Terms of trade, 1875-2006 (1993 = 100). Source ECLAC Office in Buenos Aires

flourished thanks to the natural protection provided by high import prices. As indicated by the research of Villanueva (1972), the 1920s were a particularly active period in terms of the development of the industrial sector in Argentina. International conditions worsened again in the 1930s, leading to another wave of endogenous industrialization. As the economy began to produce goods that it had imported in the past, it naturally began to close itself off from the world economy. ${ }^{8}$

The decline in the terms of trade harmed both service workers and landowners. However, the situation was less appalling for workers, since capital and labor were shifting to the secondary sector. The flow of workers to the urban secondary sector was primarily composed of people from rural areas. Their welfare began to increase as capital was reallocated to its most productive uses and as new manufacturing activities prospered. In the model presented in the previous section, this is reflected by a shift from specialization in production toward diversification and trade.

The early industrialization process of the inter-war period was accompanied by the consolidation of the labor movement. Argentine unions date back to 1877, but active unionism did not start until the twentieth century. Union demands centered on basic improvements in working conditions, some sort of insurance for work-related injuries and the prohibition of child labor. As industry blossomed and wages rose during the 1920s, the unions succeeded in having their demands met (see Galiani and Gerchunoff 2003). The Great Depression put an end to the workers' bonanza, however. Unions tried, without much success, to prevent wages from falling, but

\footnotetext{
${ }^{8}$ Of course, the size of the market played an important role in promoting industrialization. In others words, the same shock, in a much poorer country, although might promote industrialization for export activities, it would not necessarily lead to import substitution.
} 
they did succeed in retaining most of their achievements in terms of working conditions. The union movement was seen by employers as a lesser evil that would maintain industrial peace, while workers saw it as a reliable tool for protecting their rights. Unions thus emerged as an institutional device for coping with the conflict of interest between capitalists and workers in the incipient process of industrialization during the inter-war period. The battleground was the shop floor, and the conflicts were mainly about the improvement of working conditions and wage stability.

It is somewhat ironic that the debate about protectionism became a permanent fixture in the national dialog in the wake of the Roca-Runciman Treaty, which was devised to protect the Argentine primary sector and ensure exports to Great Britain. In exchange, Argentina promised to reduce tariffs on British imports and made other concessions to British companies that operated in the country. Although the treaty was not fully honored by Argentina, it did spur the debate about the role of industry. For the first time, industrialists began to call for economic independence, selfsufficiency and autarky as Argentina's answer to the new international order and continued to do so during the uncertain period of the Second World War.

This process of import substitution intensified during the Second World War under the shelter of the trade barriers associated with the war. By the end of the war, the manufacturing sector was playing a significant role in the economy, but manufacturers were arguing that a strong policy of commercial protection and subsidies was needed for them to survive, especially if the terms of trade were likely to improve. It was under the leadership of General Perón, in the midst of a major political shift, that these demands were to be fulfilled.

\subsection{A new Argentina}

The 1930s world economic crisis had profound effects on the economic and political life of Argentina. Certainly, much of the development of Argentine foreign trade seen during the 1930s, 1940s and early 1950s can be seen simply as a consequence of trade agreements and exogenous shocks coming from the rest of the world. The crisis and its immediate consequences were also a shock for the political life of the country. By the same token, the economic changes that were occurring also triggered major changes in the socioeconomic structure which ultimately created conditions conducive to the development of a populist mass movement.

Argentine politics was monopolized by the landowning elite until 1916, when a major political shift occurred thanks to an electoral reform law passed in 1912 which ushered in universal adult male suffrage (though it restricted the right to vote of the large number of unnaturalized immigrants), secret ballots and compulsory voting. Despite its apparently democratic implications, this reform was designed to perpetuate the prevailing oligarchic system by extending the vote to the urban middle class, whose members had taken part in the economic expansion in the sense that they were working in the service sector, although they had been excluded from the strongholds of power. Not surprisingly, the oligarchic elite that ruled the country believed that middle-class workers were committed to maintaining the existing political and economic structure. 
This experiment in limited democracy (the new electoral law gave voting rights to nearly one million adult males, but this was no more than approximately $40 \%$ of the adult male population) was interrupted in 1930, when the army carried out a coup and installed itself as the dominant factor in Argentine politics. Over time, the popular base of the democratic system expanded. In 1946, 3.4 million adult males had voting rights (see Cantón 1968). Thus, the voice of the people in the Argentine political system grew substantially between 1916 and 1946, despite the intervening military coup. By 1946, the economic configuration had changed dramatically. The political alignment between landowners and workers had broken down. Instead, workers-now mainly employed in the secondary sector-found their perfect ally in the capitalists of the manufacturing sector, because their political preferences were aligned both in the short and in the medium terms (see Sect. 3.2). Under Peronist policies, more capital and labor shifted to the secondary sector, thereby furthering the process of industrialization and consolidating both this alliance and the urbanrural conflict.

At that point, distributive conflict between urban factors of production and landowners emerged and paved the way for the possibility of populism as an equilibrium point. Rogowski (1989), among others, argues that backward economies with abundant natural resource endowments in which both labor and capital are relatively scarce are likely to display political cleavages that are protectionist in nature. The urban manufacturing sector will seek to protect itself, by taxing both exports and imports, against rural activities. However, this analysis, which was widely applied to Argentina during the Perón era, is at best incomplete, as our model demonstrates. This prediction holds only for certain configurations of the parameters of the model and certain histories. In particular, we stress that protectionism and protectionist cleavages arise in resource-rich economies after the potentially protected activities are initiated spontaneously in response to changing market conditions (see also Galiani et al. (2010) for a discussion on the role of skilled labor and unskilled labor in the formation of political coalitions in this context).

By 1940, the labor movement had matured; moreover, industrial capitalists had been aspiring to self-sufficiency and economic independence ever since 1930. Conditions were therefore ripe for Perón to build a mass workers movement. He started to engineer this when he was the Labor Secretary, right before he was elected President in 1946. Industry-wide bargaining was instituted; labor courts were set up to enforce the rather progressive new labor laws, social security coverage was greatly expanded, minimum wages were increased and the system of aguinaldo (1 month's extra pay at Christmas time) was introduced. Finally, Professional Associations Act was adopted in 1945, which provided for the withholding of union dues by employers, recognition of only one union organization per branch of activity and direct union participation in political activity under state supervision. As a result, the growth of union density during the 1940s was astonishingly rapid, rising from $10 \%$ in 1936 to $40 \%$ in 1948 and to $49 \%$ in 1951 (see Galiani and Gerchunoff 2003).

In this manner, a new national populist coalition was brought to power in 1946 under the leadership of Perón. The Peronist coalition left behind the traditional 
dispute between radicals and conservatives that had marked the political arena since the electoral reform. This pattern of opposition was replaced by one which had a greater share of class content and was rooted in the expansion of social rights and the political and social integration of the working classes. Indeed, the political history of Argentina in the twentieth century is divided into two: before and after the emergence of Peronism (see Torre 2002).

\subsection{The Peronist era (1946-1955)}

By 1950, most of the countries of Latin America had implemented an importsubstitution strategy. Although it was a pragmatic endogenous response to the conditions created by the Great Depression of the 1930s and the Second World War, this strategy was not necessarily the optimal response to the new international conditions of the post-war era. To a great extent, the decision as to what sort of strategy would be the best depended on what could be expected of the future evolution of the international economy. By the late 1930s, it was reasonably clear that the laissez-faire approach was finished in international economic relations. In this context, the import-substitution strategy can be seen as a defensive measure against an uncertain future of trading relations.

Clearly, world market conditions were more favorable to Argentina in 1943-1955 than in 1929-1943. After the war, policymakers had an option which they had not had during the Great Depression: to guide economic growth on the basis of expanding exports of both rural and manufactured products (see DíazAlejandro 1970). Indeed, this was explicitly attempted under the economic leadership of Federico Pinedo during the early 1940s. Pinedo's plan was a well thought out attempt to recover the dynamism of the agricultural sector and to promote export-led industrialization (see Llach 2002). However, Pinedo's strategy failed to take hold. One of the reasons for this failure is that it was opposed by the new dominant electoral coalition formed by urban capitalists and workers, who stood to benefit from a deepening of the import-substitution strategy (see Sect. 3.3). This electoral coalition would elect Juan Perón as President of the country in 1946 in what were arguably the first truly free and democratic elections with universal male suffrage.

Perón decided to consolidate the social base of his movement by redistributing income to the working classes. In fact, he saw industrialization as a mean of achieving the goals of his nationalistic and populist policy of increasing the real consumption, employment and economic security of the masses of workers (see Gerchunoff 1989).

Indeed, as Fig. 5 shows, the share of wages on GDP peaked during the Peronist era. It is clear from the figure that the share of wages in GDP is lower when the economy is integrated into the international economy than under autarky when the secondary sector has exhausted its possibilities of import substitution. Notice that this stylized fact is consistent with our model. In the long-run, the equilibrium workers' share is equal to $\left(1-\phi_{\mathrm{a}}-\phi_{\mathrm{m}}\right)+(1-\beta)\left(Y_{\mathrm{m}} / \mathrm{GDP}\right)$, i.e., the share of services in consumer preferences plus the share of labor in the secondary sector times the share of industrial output in total GDP. Notice that in the long run, and 


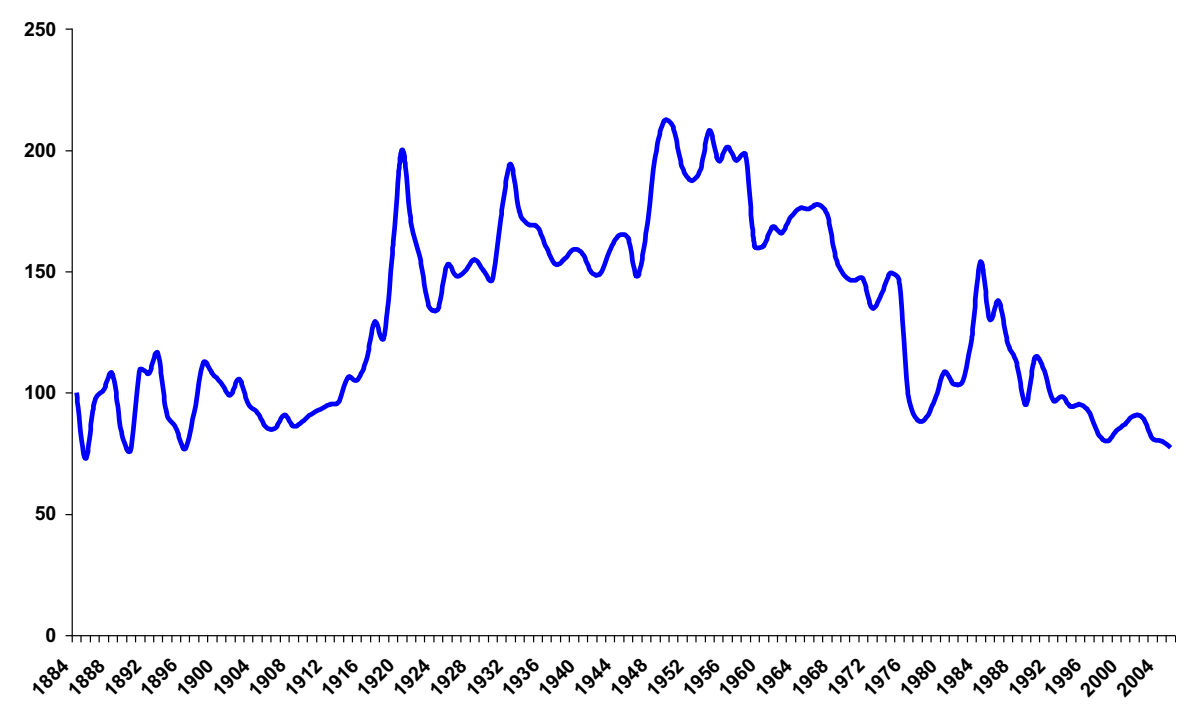

Fig. 5 Share of wages in GDP (index: $1884=100)$. Source Gerchunoff and Llach (2004)

perhaps even in the medium run, workers not necessarily are better off under autarky (see Sect. 3.3 and Proposition 7).

The Peronist policy of import substitution was not an integrated, well thought plan. Rather, there was a great deal of improvisation in its application as policymakers reacted to short-run economic and political pressures. Clearly, toward the end of the war and during the early post-war years, the government's main concern was to defend the industries that had arisen and expanded prior to and during the war, regardless of their efficiency (Díaz-Alejandro 1970). The protectionist measures that were used included not only high tariffs on imports of goods that were also produced domestically, but also the requirement that farmers sell their crops to a state trading monopoly ${ }^{9}$ that would profit from the difference between world prices and the prices paid to producers.

Import substitution gave the Peronist state control over resource allocation in the economy. By deciding which industries to protect and where to channel national credit, the Peronist government was able to discipline industrialists and determine the destination of investment. Either industrialists complied with the demands of the government or they were forced out and their capital was nationalized. The nationalization of private capital and Perón's military ambitions explain why the government became so deeply involved in the economy. Labor was also kept in line by the Professional Associations Act. Only one union was allowed to operate in

\footnotetext{
9 The Junta Reguladora de Granos, created in 1933, was transformed into the Instituto Argentino de Promoción del Intercambio (IAPI) in 1946. The JRG and IAPI worked in very different ways. The JRG operated in a period when external demand for agricultural products was weak. The goal of the JRG was to control supply to prevent domestic prices from falling. It benefited producers at the expense of consumers. The IAPI worked in the opposite way in a period when external demand was strong. It profited from buying from domestic producers below international prices. As a result, domestic prices were kept in check, benefiting consumers at the expense of producers.
} 
each branch of activity; obviously, the government was entitled to decide which one could do so if two or more unions vied for the same branch. Outlawed unions had their bank accounts frozen and their offices closed.

As a result, the Peronist government cemented a closed-economy and importsubstitution model for the years to come. The most important government intervention during the period 1945-1975 was the introduction of a relative price system which favored industry (and particularly labor-intensive industry) at the expense of the agricultural sector. As a consequence, internal relative prices diverged from international market prices, thus generating a sharp differential (which put the agricultural sector at a disadvantage) between the internal and external terms of trade (see Díaz-Alejandro 1970; Mallon and Sourrouille 1975). The triumph of the industrialization model under a closed economy, over time, and even after the demise of Perón, led to the adoption of a scheme of industrial integration which consisted of completing every step of the production process, from capital goods and inputs to final goods, inside the country's borders, in evident contradiction with the post-war tendency of developed countries, whose trade was and continues to be mainly intra-industry (see Llach 2002).

Behind these economic policy decisions, there was an alliance of economic and political interests formed by unions, industrialists and the armed forces. Unions consolidated their power by delivering better wages, working conditions and social protection to their members. Industrialists had achieved a considerable level of protection from competition. Finally, the military took the development of the steel and oil industries under its wing. Although this alliance was evidently born after the Peronist years, it had sufficient resilience to last even through the military governments and the periods of political proscription of Peronism (see, among others, Halperín Donghi 1994; Llach 2002). ${ }^{10}$

Up to now, we have been assuming that the economy operated near the efficiency frontier. This is reasonable if we assume that capital allocation and employment decisions were made in a decentralized way by profit-maximizing agents. However, during Peronism and the years that followed until the collapse of the importsubstitution model, the assumption is hard to maintain. Capital was allocated on the basis of political rather than economic considerations. Labor allocation was no less distorted: public employment was used as a means of combatting unemployment; moreover, unions regulated quantities and prices in their members' labor markets to the extent that they were politically able to do so.

Not surprisingly, income redistribution and industrial promotion policies rapidly ran up against a formidable constraint: exports stagnated (see Brambilla et al. in this volume). It is true that the stagnation of Argentine exports can be partly attributed to the global closure of markets and to the protectionist policies applied by industrial countries in agriculture that favored self-sufficiency (especially in Europe). However, it is also true that Argentina underperformed even in comparison to other countries that shared the same markets.

\footnotetext{
10 This alliance was very effective at maintaining and obtaining new rents from the state (see Mallon and Sourrouille 1975).
} 
Argentina accounted for more than one-third of all Latin American exports in 1928, one-fourth in 1938 and only one-eighth in 1954. It exported mainly primary goods: corn, wheat, linen, wool and meat. The joint share of these five goods in world trade declined from $8.6 \%$ in 1926-1929 to $3.9 \%$ in 1960 . Nevertheless, the fact that Argentina's market share was halved during that period provides evidence of Argentina's decline relative to other agricultural exporters. Overall, if we consider the world exports of these five primary products, Argentina accounted for $1.8 \%$ of those exports in the late 1920 s and for only $0.4 \%$ in 1960 . If we analyze export trends by product, we see that, in that same period, Argentina's market share in corn decreased from $57 \%$ to $21 \%$, in wheat from $20 \%$ to $9 \%$, in linen from $73 \%$ to $40 \%$ and in meat from $40 \%$ to $24 \%$, while its market share in wool remained unchanged at around 6\% (see Llach 2006). The stagnation of Argentine exports placed an inescapable constraint on the country's growth.

In sum, during Peronism Argentina embarked on an ambitious import-substitution industrialization process backed by a coalition of industrial capitalists and workers. In the language of our model, the protectionist policies drove the economy from the diversification and trade area to a near-autarky situation.

\subsection{A nation in Deadlock (1955-1973)}

Toward the end of the 1950s, it was becoming clear that the world was entering a new free trade era and that the woes of the inter-war mercantilist period were over. However, taking advantage of the new international conditions required a painful period of readjustment. In terms of our model, as capital flows back to the primary sector, industrial capitalist and workers suffer the most, whereas landowners benefit greatly. At the domestic level, it was also clear that the shift toward the consumption frontier for mass-produced, labor-intensive domestic goods had come to an end. Steel, machinery, motor vehicles and petroleum were the activities that were being protected and promoted during this new phase of import substitution in Argentina, and all of these industries were more capital intensive than those targeted during the initial state of import substitution (see Mallon and Sourrouille 1975).

Perón himself, after being reelected by a landslide, was seeking an economic alternative that would have inevitably entailed major economic and social readjustments. Nonetheless, Perón had taken notice of the political risks of departing from the path that had until that point driven him toward the amplification of redistributive policies and import-substitution strategies. Indeed, Perón was ready to abandon nationalism to attract the foreign capital needed to sustain the deepening of the import-substitution model, but not to revert the improvement in the distribution of income achieved under that model. Under these conditions, the armed forces abandoned their alliance with the unions and industrialists. Highranking officers were becoming increasingly worried about the path that Argentina was taking under Perón's rule. They silently plotted against Perón and forced him to withdraw in 1955.

Interestingly enough, all the governments between 1955 and 1973 tried, to the extent of their possibilities, to deepen the import-substitution process, which was still backed by an increasingly weakened coalition of workers and industrialists. The 
social revolution embodied by Peronism created a new society that took on a life of its own and that, even though it had no way to survive, simply refused to die (Halperín Donghi 1994).

On average, export incentives were larger during the period 1955-1973 than during the first post-war decade. But the policy tilt toward import substitution and away from exports remained a feature of the Argentine economy during the period 1955-1976. Argentina's effective rates of protectionism remained the highest in Latin America (Díaz-Alejandro 1984). Protectionism and hostility toward the rural producers of the pampas were hardly limited to the Peronist movement, neither was a strong nationalist stance toward foreign capital. As with export incentives, governments zigzagged in their policies toward foreign capital during this period. However, foreign corporations were nonetheless used as key instruments in expanding industrial production in consumer durables and in intermediate and capital goods (Díaz-Alejandro 1984).

These years also saw a steep increase in the consumption of services, many of which were provided by highly educated workers, for whom there was a strong demand in this sector. These educated workers began to break down the rural-urban political cleavage (see Galiani et al. 2010). As a result, the shift toward the promotion of more capital-intensive industries and the growth of a services sector catering to high-income and upper-middle-income groups gradually eclipsed distributionist protectionism.

Over time, sustained growth required more government intervention. The state had to finance the deficits run by public-sector enterprises, subsidize the substitution of capital-intensive imports and promote non-traditional exports. Yet it became less and less able to do so as trade revenues began to shrink under increasing autarky and as the surplus enjoyed by the social security system created under Perón melted away, turning into a deficit by the mid-1960s. The inflation tax thus became the adjustment variable for an increasingly conflict-ridden and inviable society (see Mallon and Sourrouille 1975).

The alliance between industrialists and workers began to grow stale. Labor unions faced a dilemma, since preventing wages from going down required limiting the supply of workers, and they knew all too well that having fewer members implied less power. They also knew, of course, that new investment in unionized activities would allow them to achieve both higher employment and higher wages. In sum, they needed modern and capitalized industries, but their own power kept capitalists away. The solution to the dilemma was direct government intervention and direct investment in industrial activities.

The alliance between workers and industrialists was also unstable. They both wanted high protection for industry, and hence their interests were aligned in this respect. However, their interests conflicted with respect to real wages. Thus, from time to time, when the economy needed to adjust to its consumption possibilities, the alliance would break down for a time (see O'Donnell 1977).

To complete this dim picture, some workers became increasingly disappointed with their union leaders and found hope in the promises of a "socialist fatherland" made by leftist groups. These groups accused the landowners of serving foreign interests and being unpatriotic. To differing degrees, depending on each group's 
political orientation, they proposed various strategies, with the most extreme one being the outright expropriation of land and its redistribution among the people by means of revolutionary violence.

To sum up, chronic inflation and recurrent cycles of recession and recoveryassociated with substantial changes in income distribution arbitrated by the state (see Mallon and Sourrouille 1975; O’Donnell 1977)—were salient economic features throughout this period (and even beyond it). At the same time, social and political divisions grew increasingly tense, reaching such a point that violence dominated the political and economic life of the country. As a result, Argentina failed to regain its prosperity and to achieve a consensual political order; instead, it was stumbling along in a volatile stalemate. The successive administrations proved unable to prevent the progressive institutional decay of the country. Nevertheless, the darkest hour for Argentina was yet to come.

\subsection{Crisis and reforms (1973-2010)}

The intervention of the state in the economy increased substantially during the Peronist era and the next 20 years. There is a stark contrast between the industrialization process of the period 1920-1945 and that of 1946-1975. In the former, the private sector reacted to the shortage of foreign manufactured goods and led the way toward endogenous industrialization. In the latter, the state took an active role in deepening the import-substitution process. This led to decisions based on political expediency rather than economic rationality.

The industrialization process was guided by an alternation of administrations with different strategic objectives, so it is not surprising that, overall, we find that it failed to achieve self-sufficiency or even a more rational or coherent industrialization process. This led to an essentially disproportionate development process that promptly ran into binding constraints: (a) the inadequate growth of exports was a very serious obstacle to the industrialization process, which required growing inputs of capital and intermediate goods; and (b) the intensification of the industrialization process, especially the development of heavy industry, required larger subsidies that needed to be financed in some way. The government's inability to accomplish this task with fiscal resources drove inflation up to levels that were inconsistent with a healthy economic performance.

A final populist experiment (under President Perón and then his wife) in the early 1970s ended up in economic and political disorder. On the political side, it failed to curb the spiral of violence that leftist guerrillas had ignited in the late 1960s. On the economic side, the oil crisis exposed the weakness of the import substitution strategy. The increase in the price of imported oil, a vital input of the manufacturing sector, fueled inflation and reduced real wages. ${ }^{11}$

A top-down disciplinarian military administration then took its place. The main economic objective of this government was to reduce inflation. A significant, although gradual and partial, market-oriented financial and trade liberalization

\footnotetext{
11 Recall that in our model, the oil price hike can be interpreted as a negative productivity shock to the manufacturing sector.
} 
program was also implemented. This time, the military government was quite intransigent in its attitude toward the other groups within the weakened industrialist alliance. In disciplining the unions, the military government not only suppressed collective bargaining and other union rights, as it had at other times in the past, but actually used its military might against union leaders, some of whom became victims of kidnappings and forced disappearance at their hands. Nevertheless, the unions were not entirely decimated and, after the return to democracy some years later, they were again a very powerful social force in the country. Industrial businessmen were also disciplined through trade liberalization measures.

The discipline imposed on both labor and capital was not reflected in fiscal austerity. With favorable international conditions for credit, the military-industrial complex was empowered, and public spending on infrastructure soared. Large business groups were also able to modernize considerably thanks to their easy access to cheap credit. Over time, both inflation inertia and the prevalence of large fiscal deficits made the exchange rate system of pre-announced gradual devaluations, which had been adopted to control inflation, unsustainable. Between 1979 and 1981, capital flight amounted to around 20\% of GDP, leaving the government (which absorbed private sector external debt) with a hefty external debt that has influenced the country's economic performance ever since.

The country's extraordinary debt rates paved the way for a fiscal and balance-ofpayments crisis that dominated the political and economic scene during the 1980s. Throughout the 1980s, the Argentine economy posted the worst performance it had turned in at any time since the end of the Second World War. Investment collapsed. Per capita GDP decreased by approximately 20\% between 1980 and 1989. Inflation was above $100 \%$ for every year except 1986 . Both the external debt and the debt-toexports ratio rose at an ominous pace. The dollarization of the economy deepened, increasing its financial fragility. Ultimately, in the presence of severe uncertainty at a time when the country was making its first democratic transition in decades, its high inflation gave way to a short but devastating bout of hyperinflation.

It was only after a brutal episode of hyperinflation that a comprehensive reform process was adopted (see, among others, Acuña et al. 2007). In the wake of its trade and financial reforms of the 1970s, Argentina had embarked upon a process of integration into the international economy. This was substantially deepened during the 1990s, when the Peronist administration privatized state enterprises and drastically reduced import tariffs and export duties. Labor unions, which had blocked free trade policies since 1955, were unable to effectively oppose these reforms (see, however, Acuña et al. 2007, for a discussion of how the government seduced union leaders into supporting the reformist agenda).

Although not without large social costs, measured by a substantial increase in poverty and inequality (see Alvaredo et al. in this volume), this reform process finally moved the Argentine economy toward a rational form of integration into the world economy. The recovery of the agricultural sector and the growth of exports have been spectacular (see Brambilla et al. in this volume). The surviving industries are realistically competitive and largely oriented toward the manufacturing of the natural resources with which the country is abundantly endowed (see Brambilla et al. in this volume). 
The Peronist party (Justicialist Party) continues to dominate the political arena, having held office for 18 years in the period 1990-2010. Its support base has changed somewhat though. Now, its supporters can be found not only among unionized workers and public employees, but also among a large number of informal service workers and small rural producers. The challenge of the twentyfirst century for the Peronist party is to build an alliance with landowners and rural producers in the pursuit of an export-led form of growth without losing the support of the vast number of people living in poverty as a result of 50 years of economic stagnation and a painful trade liberalization process. The prospects are not brightthe Peronist party has increasingly used political clientelistic practices to retain the support of the poorest segments of the population.

In the language of our model, the reform process initiated in the 1990s redirected capital to the primary sector and labor to the tertiary sector within the area of diversification of production and trade. The balance of power shifted away from the industrialists and toward the coalition of agricultural producers and service providers. During the 2000s, the improvement in terms of trade has helped them to consolidate their power. The distributional conflict has not disappeared; there are urban sectors that would benefit from an increase in protectionism. However, the pro-agricultural coalition appears stronger than in the past. Indeed, in March 2008 a government attempt to increase export taxes on soybeans and sunflower was met with a nationwide lockout by farming associations. The proposal was finally defeated in Congress after 4 months of large-scale demonstrations in urban areas and road blocks in rural areas. ${ }^{12}$ However, as we learned from the country's experiences in the early twentieth century, such coalition between landowners and service workers is viable only under favorable external conditions and it is politically weak.

\section{Why Argentina?}

We have analyzed the economic history of twentieth-century Argentina as seen through the prism of a model that is a tractable, yet seemingly adequate, simplification. The model allows us to derive the preferences or attitudes of each socioeconomic group regarding protectionism. Without being explicit about the political process that determines the taxes on international trade, we have been able to support our main claim: the negative external shocks faced by the economy during the first half of the century spurred an endogenous industrialization process that had a profound impact on the political landscape of the second half of the century. Over the first half, capital and labor were reallocated from the primary and tertiary sectors to the secondary sector, and this changed the attitudes of the majority of the population with respect to protectionism. The import-substitution industrialization process was, in part, a response to those attitudes.

\footnotetext{
12 In appendix B, we exploit this natural experiment to provide evidence that: (a) trade policies are still a key component of electoral competition; and (b) the coalitions vote as suggested by our model.
} 
The argument presented in our model is similar to the Stolper-Samuelson (1941) result: if labor is assumed to be employed less intensively in the production of the exportable good, then protection should increase its real remuneration. However, once we include the labor-intensive non-tradable sector, this prediction no longer holds; with favorable terms of trade, wages can be higher under free trade (see also Galiani et al. 2009). ${ }^{13}$ In this case, path dependence is introduced by assuming that physical capital adjusts slowly and that impatient workers are the pivotal group in the political process. The attitude of labor toward protectionism depends on the allocation of capital that is assumed to be fixed in the medium run. This is also very relevant because it helps to explain the entire economic history of Argentina between 1870 and the present within a unified framework. In contrast, in the previous literature, the widely used Stolper-Samuelson theorem only helps to understand the rise of the urban-rural political cleavage that appeared following the Second World War, but it cannot account for the periods of integration into world trade seen in the late nineteenth century and after the fall of the Berlin wall.

At first sight, it seems that this type of path-dependent anti-trade trap could have appeared in any economy; however, we claim that this is not the case. It is true that endogenous protectionism can arise in almost any economy if we assume some adjustment costs and persistent external volatility in the terms of trade. However, if the underlying distributional conflict is not too intense, the economy can gradually steer itself toward a more efficient pattern of trade. It is the intensity of the distributional conflict — determined mainly by technology and factor endowmentsand the inability to resolve it by institutional means that place Argentina in a special situation.

Our model has three features that generate both path dependence and intense distributional conflict. First, the production of the exportable good does not use the pivot input-labor-intensively. Otherwise, the pivot group would tend to support free trade policies in the short and medium run. Second, the exportable good is an important component of the consumption bundle. Otherwise, it is possible to show that, in the medium run, workers would prefer a tariff level that decreases with the terms of trade; in that case, workers would prefer gradual liberalization as the terms of trade improve. Third, at the point in time when the terms of trade worsen, the economy has to have enough capital to start the endogenous industrialization process. Poor economies that have not accumulated enough capital yet are less prone to the severe distributional conflict described here. These three conditions fit fairly well for Argentina and point to what other economies we should look at in an effort to discern protectionist traps. We focus on land-rich newly settled countries, particularly Australia, since there is a long tradition of comparing Argentina with Australia in the literature (see, among others, Díaz-Alejandro 1984; Gerchunoff and Fajgelbaum 2006).

\footnotetext{
13 With capital mobility, wages are a U-shaped function of the terms of trade. Wages are high either under specialization and trade with favorable terms of trade, or under autarky or reversal of the terms of trade. The lowest wages are at the frontier between specialization and diversification.
} 


\subsection{Argentina and Australia}

There are a number of similarities between these two economies that make this exercise of comparative history worthwhile. First, their initial endowments, that is, the relative scarcity of labor relative to land, determined their position as exporters of agricultural goods. Second, there is the natural emergence of manufacturing sectors in response to the natural protection provided by exogenous international conditions and the distance of main industrial centers. Third, there is the demand for protectionism by urban manufacturing interests. As a result, both countries relied heavily on tariffs and quantitative restrictions to trade to provide protection for their manufacturing sectors. These policies were blamed for the relatively poor performance of these economies and were eventually abandoned by the end of the twentieth century, although not without opposition from vested interest groups.

Anderson (2002) states that "seven decades of import-substituting industrialization cost Australia dearly in terms of its comparative standard of living. In 1900, Australia was arguably the highest-income country in the world on a per capita basis. But by 1950 its rank had slipped to third; by 1970 it was eighth; and by the 1990s Australia was not even in the top twenty" and that "Australia's comparatively poor growth performance for most of the twentieth century contrasts with that of the final decade, when Australia out-performed all other advanced economies other than Ireland and Norway". The author claims that part of that success is attributable to the "belated opening of the Australian economy to the rest of the world".

The differences between these two cases start to appear when we focus on the intensity of the distributional conflict and the institutional settings where this conflict needed to be resolved. We claim that the Argentine distributional conflict was more intense and that its institutions were weaker. As a result, while Australia was able to overcome its conflict, Argentina was overwhelmed by it. Moreover, international and geopolitical conditions helped to ease the Australian anti-trade, trap but not the Argentinian one. In what follows, we stress some key differences between these two economies and show how they contribute to our argument.

\subsubsection{From endowments to institutions}

Since its creation in 1901, the Australian Federation adopted protectionist trade policies that were strengthened during the course of the twentieth century up until 1973, when the country entered into a gradual but steady process of liberalization (see, among others, Anderson 1998, 2002; Anderson and Garnaut 1987; Corden 1996; Garnaut 2002).

The Australian gold rushes of the late ninetieth century sparked an early influx of immigrants who helped to consolidate a mining export sector. The mining sector had powerful forward and backward industrial linkages that generated interest in scientific and technical research, as well as giving rise to a unionized labor force across the economy. The trade unions and entrepreneurs involved with mining coalesced into political groups that opposed the creation of a ruling landowning elite. 
In 1901, the Labor Party joined the Protectionist Party to form the first government of the Australian Federation. Two key issues on the political agenda were the level of protectionism and immigration policy. The government successfully passed the Immigration Restriction Act of 1901, which formed the basis for the White Australia Policy. However, the government had to reach a compromise with the Free Trade Party to set import tariffs in 1902.

Australian immigration policies have been substantially different from those of Argentina. As mentioned before, the Argentine elite chose to promote immigration. Argentina's population went from 1.35 million in 1861 to 11.28 million in 1928 , while, in Australia, it went from 1.2 to 6.22 million. In Argentina, this decreased wages and increased the return on land. Indeed, Taylor (1997) calibrates a general equilibrium model to estimate the impact on wages of the massive flow of immigration to Argentina up to the First World War. His calibration suggests that the flow of immigration reduced real wages in Argentina by approximately $20 \%$ from what wage levels would have been if immigration had not taken place.

What is more, and in spite of similar factor endowments, land was more concentrated in Argentina than in Australia, where family-operated, medium-sized farms were relatively more common. As a consequence, landowners in Australia did not constitute an oligarchy as they did in Argentina; they were a broad social group and were not a ruling class. Landlords in Australia never controlled the governmental machinery as they did in Argentina (see Hirst 1979).

To sum up, by the beginning of the twentieth century, the Australian labor movement was already mature and consolidated, had an active role in the policymaking process and had successfully demanded protection and restrictions on the flow of immigrants. However, it was not a hegemonic party; it had to make compromises with the Free Trade Party, which represented the interests of the agricultural sector. In Argentina, the ruling elite had vested interests in the agricultural sector and did not need to compromise with antagonistic interest groups. Even before the 1930s crisis, Australia was already experiencing a distributional conflict similar to the one described in our model, and it found institutional ways to deal with it. In practice, Australia had a democratic government, while Argentina had an autocratic government ruled by the oligarchic landlord class.

Australia's stronger institutions also translated into better policymaking. In 1921, the Australian government moved to protect the industries that had expanded during the war; however, recognizing that vested interest groups would attempt to influence the policymaking process, it established the Tariff Board, an advisory body composed of "disinterested experts" to provide technical advice to both the Parliament and the Minister for Trade and Customs. This development had two direct benefits that would facilitate the process of liberalization. First, as noted, it reduced the direct influence of interest groups. Second, it created a bureaucracy with technical expertise on the matter.

The Australian factor endowment also helped to reduce the intensity of the distributional conflict. While Argentine exports were mainly agricultural goods, an important component of the consumption bundle, a large share of Australian exports 
were mineral products that do not enter directly into the consumption bundle. Free trade policies were more harmful to Argentine workers.

\subsubsection{Liberalization}

By the late 1960s, there was consensus among Australian economists on the benefits of import liberalization. These views came to be adopted first by the members of the Tariff Board and then by politicians. However, public opinion continued to show support for protectionism. Interestingly, the first move toward liberalization was in 1973 under a government led by the Labor Party, whose constituents tended to be stronger supporters of protection. From then on, Australia embarked on a gradual but steady path toward free trade. This process was facilitated by favorable external and internal conditions that reduced the intensity of the distributional conflict and by properly functioning institutions that made intertemporal bargaining possible.

The rise of Eastern Asia as a potential trading partner that was interested not only in Australian raw materials but also manufactures shifted the Labor Party's views on protectionism. Closer integration into the regional economy through trade liberalization would increase the demand for exports of manufactures that were more labor-intensive than traditional exports (see Díaz-Alejandro 1984; Gerchunoff and Fajelbaum 2006).

Not only Labor Party leaders, but also the Australian Council of Trade Unions (labor) and the Business Council (mining and service industries) advocated free trade. Recognizing the effects of protection on export performance, both farming and mining groups joined the public debate. At a federal level, the exporting states also supported liberalization. The textiles, clothing and footwear, and automobile industries, which enjoyed ample protection, invested heavily in political activity aimed at maintaining protectionism. However, these industries were already declining by the mid-1970s and they were further weakened by successive tariff reductions from then on (see Garnaut 2002).

These external and internal developments changed the nature of the distributional conflict associated with trade policy. Only capitalists and workers employed in import-competing activities would oppose liberalization in the short run. However, as part of a gradual, steady and predictable process of liberalization, new capital investments were redirected toward activities that were not dependent on protection, while, at the same time, vested interests were not harmed. The role played by the institutions and the political leadership that took part in this task is remarkable. The political system was able to set long-term policy goals to guide economic activity without imposing large adjustment costs in terms of output or employment.

In contrast, during the early 1970s, Argentina was immersed in what was tantamount to a civil war in which leftist groups were trying to create a socialist country that would expropriate the holdings of the oligarchic landlords and transfer the land to poor rural workers. Even when the economy was opened to trade during the second part of the 1970s, this was not done by consensus. Instead, it was the result of a unilateral decision made by a military government aligned with landlords and the capitalists that could survive integration with the world economy and that were threatened by the fierce distributive conflict that arose during the last Peronist 
government. The second attempt to integrate the country with the world was made during the 1990s, after a devastating episode of hyperinflation, by a government that campaigned on a populist agenda. Both these attempts were abrupt and were conducted as shock policies by political groups that had political power but did not represent a consensus view on the part of the population. Thus, trade reform was abrupt and did not provide any way to smooth out losses. Even today, when serious attempts to restrict trade are being made by the current government, a large segment of the population sees the two episodes of trade liberalization as disastrous.

To sum up, the distributional conflict in Australia was mitigated both by a differential initial factor endowment that led to the appearance of different organizations and institutions in society and, later, by the rise of East Asia as a trading partner. Moreover, Australian institutions were well suited to pursue a gradual process of adjustment to minimize the losses of those who had sunk investments in protected industries, while Argentine institutions and organizations did not display those capabilities. In a context of policy path dependence, all these differences ended up making a substantial difference in the outcomes.

\section{Concluding remarks}

Up to the 1930s, Argentina was well integrated into the world economy and, though some protectionism naturally developed after the Great Depression of the 1930s, it was only after the Second World War that the country closed itself off from world markets. It then remained in a situation close to autarky until the mid-1970s. It was only after a long period of absolute economic decline and a devastating bout of hyperinflation that a comprehensive program of reform and integration into the world economy was adopted.

We use a model with two tradable goods and one non-tradable good. We assume that Argentina has a comparative advantage in the production of agricultural goods. Thus, it might or might not produce manufactured goods. It also produces services. We assume that the agricultural good is produced in the primary sector using land and capital, while the manufactured good is produced in the secondary sector using labor and capital. Services are produced using labor only. We also assume that capital moves between the primary and secondary sectors more slowly than labor moves between the secondary and tertiary sectors. This gives rise to three different time horizons: the short run (no factor reallocation), the medium run (only labor adjusts) and the long run (full reallocation).

We show that import-substitution policies exhibit path dependence. Indeed, this is a very important insight in understanding the economic history of Argentina. We also use our model to characterize the demands for protectionist policies of the different groups in the economy. In the short run, landowners, capitalists who have invested in the primary sector and workers employed in the tertiary sector support free trade policies. On the other hand, capitalists and workers in the secondary sector support protectionist policies. In the medium run, workers behave as a group and will support protectionist policies if the industrial sector is sufficiently 
developed (i.e., the secondary sector employs enough labor and capital). In the long run, workers will support free trade if the terms of trade are favorable enough.

Using the insights derived from our model, we then argue that much of the distributional conflict that arose was among owners of different production inputs and that trade policies were widely used to shift income across groups. At the beginning of the century, factor allocation resembled what we call "specialization and trade." During the inter-war period, trade opportunities and the terms of trade worsened, which led to an incipient industrialization process. Argentina started the second half of the century with a very different economic configuration, as industrialization had come a long way in terms of what we refer to as diversification and trade. These new economic conditions also changed the political equilibrium. Urban workers employed in the manufacturing sector and industrialists were now major social actors who demanded that the industrialization process be deepened, which hurt trade and took the economy close to autarky. The years that followed the Second World War witnessed an extraordinary expansion of trade in which Argentina was not an active participant. We contend that one important reason behind this outcome was the set of protectionist policies that were enacted in the years following that war and that the main supporters of these policies were the new political forces that emerged from the industrialization process in the inter-war period.

The second half of the century was characterized by a strong distributional conflict centered on trade policy. Traditional sectors composed of owners of factors employed in the primary sector supported free trade policies, whereas the newer political forces supported protectionism and import substitution. Argentina embarked on an ambitious process of import substitution that aimed at achieving self-sufficiency, especially in activities deemed strategic, such as oil and steel. As domestically produced goods were substituted for labor-intensive imported manufactures, the industrial sector grew and drew inputs from other sectors. The substitution of capital-intensive activities was more problematic. Some of these activities were not profitable even though they had a captive internal market. With little regard for economic rationality, the government took an active role in developing these activities through public enterprises that became a chronic source of deficits.

Instead of delivering a steady path of inward-oriented growth, the importsubstitution strategy resulted in bumpy cycles of economic expansion followed by sharp recession. Liberalization promised a return to export-led growth; however, in the case of agents with vested interests in protected activities, it would cost them dearly. The protectionist coalition, industrial capitalists and unionized workers, had enough political power to keep liberalization off the policy agenda.

The accomplishment of gradual liberalization process that mitigated the losses of those with vested interests and the definition of clear and sound long-term policy goals required a set of political institutions capable of enforcing intertemporal agreements between political groups. Sadly, Argentina lacked such institutions. Instead, the dismantlement of the import-substitution strategy came only after the protectionist coalition had become sufficiently weakened. The steps taken toward liberalization were abrupt and were conducted as shock policies by political groups 
that had political power, but did not represent a consensus view among the population. Moreover, it did not provide any way to smooth out the losses. As a result, Argentina's integration into world markets was extremely costly in terms of inequality and poverty.

Argentina had to wait to reap the benefits of liberalization until the first decade of the twenty-first century, when favorable commodity prices in world markets fueled rapid economic growth. As the primary sector gained in productivity and received large capital inflows and as employment in the tertiary sector soared, the demand for protectionism was reduced. However, the distributional conflict centered on trade policy survived the turn of the century and remains important.

Acknowledgements We are grateful for the comments provided by editors Rafael Di Tella and Edward Glaeser, the three anonymous referees, Hugo Hopenhayn, Douglass North, Jeffrey Williamson, and seminar participants at Harvard (March 2009) and LACEA (October 2009) in Buenos Aires. We have also benefited greatly from conversations with D. Heymann and would like to thank Ivan Torre for his excellent research assistance.

Open Access This article is distributed under the terms of the Creative Commons Attribution 4.0 International License (http://creativecommons.org/licenses/by/4.0/), which permits unrestricted use, distribution, and reproduction in any medium, provided you give appropriate credit to the original author(s) and the source, provide a link to the Creative Commons license, and indicate if changes were made.

\section{Appendix 1}

In this appendix, we solve the long-run equilibrium of the model presented in Sect. 3. We also derive the effect of export taxes on real factor remuneration in the short, medium and long terms.

\section{The long-run equilibrium}

Let $\Upsilon$ denote the degree of comparative advantage of the secondary sector and $\pi$ denote the international price of the agricultural good relative to the manufacturing good, i.e., the terms of trade:

$$
\begin{gathered}
\Upsilon=\frac{M}{A} \frac{L^{1-\beta} K^{\beta-\alpha}}{T^{1-\alpha}}, \\
\pi=\frac{p_{\mathrm{a}}}{p_{\mathrm{m}}} .
\end{gathered}
$$

Moreover, let

$$
\begin{aligned}
& \lambda=\frac{L_{\mathrm{m}}}{L}, \\
& \kappa=\frac{K_{\mathrm{m}}}{K} .
\end{aligned}
$$


That is, $\lambda$ is the share of workers employed in the manufacturing sector and $\kappa$ is the share of units of capital employed in that sector. We seek to characterize the steady-state ratios $\kappa$ and $\lambda$ as functions of the technological and preference parameters, factor endowments and exogenous variables: terms of trade $\pi$ and the ad valorem tax rate on exports $\tau$.

Since land is used only in the primary sector, its outside opportunity cost is zero. Given our technological assumptions, the marginal product of the first infinitesimal unit of capital employed in the primary sector is infinite; therefore $\kappa<1$, i.e., the primary sector always employs some capital.

The demand for capital in the primary sector solves the following first-order condition for profit optimization of the representative firm in the sector:

$$
\alpha\left(\frac{1}{1-\kappa}\right)^{1-\alpha} p_{\mathrm{a}}^{d}=\frac{r_{\mathrm{a}} K}{K^{\alpha} T^{1-\alpha} A},
$$

where $p_{\mathrm{a}}^{d}$ is the domestic price of the agricultural good and $r_{\mathrm{a}}$ is the return to capital in the primary sector. Similarly, the demand for land in the primary sector, given the land rental rate, $q$, is given by:

$$
(1-\alpha)(1-\kappa)^{\alpha} p_{\mathrm{a}}^{d}=\frac{q T}{K^{\alpha} T^{1-\alpha} A} .
$$

If some capital is also employed in the secondary sector, then the demand for capital in the secondary sector satisfies:

$$
\beta\left(\frac{\lambda}{\kappa}\right)^{1-\beta} \Upsilon p_{\mathrm{m}}^{d}=\frac{r_{\mathrm{m}} K}{K^{\alpha} T^{1-\alpha} A},
$$

where $p_{\mathrm{m}}^{d}$ is the domestic price of the manufactured good and $r_{m}$ is the return to capital in the secondary sector. The demand for labor in the sector is given by:

$$
(1-\beta)\left(\frac{\kappa}{\lambda}\right)^{\beta} \Upsilon p_{\mathrm{m}}^{d}=\frac{L w}{K^{\alpha} T^{1-\alpha} A},
$$

where $w$ is the wage rate.

The Cobb-Douglas utility function that we use to represent the preferences of consumers implies that the share of each good in total expenditure is constant. Let $\phi_{\mathrm{a}}, \phi_{\mathrm{m}}$ be the shares of the agricultural and manufactured goods, respectively. Naturally, $1-\phi_{\mathrm{a}}-\phi_{\mathrm{m}}$ is the share of the service good. The aggregate demand for each good $\left(c_{\mathrm{a}}, c_{\mathrm{m}}\right.$ and $\left.c_{\mathrm{s}}\right)$ satisfies the following maximizing condition:

$$
\frac{c_{\mathrm{m}} p_{\mathrm{m}}^{d}}{\phi_{\mathrm{m}}}=\frac{c_{\mathrm{a}} p_{\mathrm{a}}^{d}}{\phi_{\mathrm{a}}}=\frac{(1-\lambda) L w}{1-\phi_{\mathrm{a}}-\phi_{\mathrm{m}}},
$$

where we have already imposed the market equilibrium condition in the non-tradable sector:

$$
c_{\mathrm{s}}=(1-\lambda) L w .
$$


In an open economy without international capital markets, trade is balanced in each period. Therefore,

$$
\kappa^{\beta} \lambda^{1-\beta} \Upsilon+\pi(1-\kappa)^{\alpha}=\frac{c_{\mathrm{m}}+\pi c_{\mathrm{a}}}{K^{\alpha} T^{1-\alpha} A}
$$

If the country is trading internationally, the domestic price of the agricultural good is $p_{\mathrm{a}}^{d}=(1-\tau) p_{\mathrm{a}}$. Due to the Lerner symmetry theorem, we assume that the import tax is zero. Therefore, we have $p_{\mathrm{m}}^{d}=p_{\mathrm{m}}$.

The following subsections solve the different types of steady-state equilibria that might exist. First, we study the autarky equilibrium. We derive the shares $\lambda_{\text {aut }}$ and $\kappa_{\text {aut }}$ and the autarky relative domestic price $p_{\text {aut }}$. This price has to be such that $\pi(1-\tau) \leq p_{\text {aut }} \leq \pi$ : it is not profitable to export or import goods. Second, we study the equilibrium under specialization in the production of primary goods. We derive the input prices $w$ and $r$ and then obtain the marginal cost of producing the manufactured good. This marginal cost has to be higher than the international price of the manufactured good. Third, we study the equilibrium under diversification and trade. We derive the shares $\lambda$ and $\kappa$ and the exports of primary goods. All of these three variables have to be positive in equilibrium. Finally, we derive the equilibrium under reversal of the pattern of trade. We proceed in the same way as in the case of diversification and trade, but now we set $\tau=0$ and we require the exports of the manufactured good to be positive.

\section{Autarky equilibrium}

We now solve the model for autarky by imposing that the consumed quantities equal the produced quantities for each of the three goods:

$$
\begin{aligned}
\frac{c_{\mathrm{m}}}{K^{\alpha} T^{1-\alpha} A} & =\kappa^{\beta} \lambda^{1-\beta} \Upsilon, \\
\frac{c_{\mathrm{a}}}{K^{\alpha} T^{1-\alpha} A} & =(1-\kappa)^{\alpha} .
\end{aligned}
$$

Using 1, 2, 4, 5, 6 and 8, we derive the following values for $\lambda_{\text {aut }}, \kappa_{\text {aut }}$ and the autarky relative domestic price $p_{\text {aut }}$ :

$$
\begin{aligned}
\kappa_{\mathrm{aut}} & =\frac{\phi_{\mathrm{m}} \beta}{\phi_{\mathrm{m}} \beta+\phi_{\mathrm{a}} \alpha}, \\
\lambda_{\text {aut }} & =\frac{\phi_{\mathrm{m}}(1-\beta)}{\phi_{\mathrm{m}}(1-\beta)+\left(1-\phi_{\mathrm{a}}-\phi_{\mathrm{m}}\right)}, \\
p_{\text {aut }} & =\frac{\beta^{\beta}}{\alpha^{\alpha}}\left(\phi_{\mathrm{m}} \beta+\phi_{\mathrm{a}} \alpha\right)^{\alpha-\beta} \phi_{\mathrm{a}}^{1-\alpha}\left(\frac{(1-\beta)}{\left(\left(1-\phi_{\mathrm{a}}-\beta \phi_{\mathrm{m}}\right)\right)}\right)^{1-\beta} \Upsilon .
\end{aligned}
$$

For autarky to be a steady-state equilibrium, $p_{\text {aut }}$ has to satisfy

$$
\pi(1-\tau) \leq p_{\text {aut }} \leq \pi
$$

Otherwise, there are arbitrage opportunities for exporting and importing goods. 


\section{Equilibrium under specialization}

A specialized economy imports the secondary good and produces and exports the agricultural good. The economy is specialized in the primary sector if there is no capital or labor employed in the secondary sector; therefore: $\kappa=\lambda=0$. For this to be an equilibrium, the wages and capital rental rate paid in the other sectors of the economy must be greater than what can be profitably paid by the secondary sector.

$$
m c_{\mathrm{m}}=\left[\left[\frac{1-\beta}{\beta}\right]^{\beta}+\left[\frac{\beta}{1-\beta}\right]^{1-\beta}\right] r^{\beta} w^{1-\beta} M^{-1} \geq p_{\mathrm{m}}^{d} .
$$

Using $1,5,7$ and 10 , setting $\lambda=\kappa=0, p_{\mathrm{m}}^{d}=p_{\mathrm{m}}$ and $p_{\mathrm{a}}^{d}=(1-\tau) p_{\mathrm{a}}$, we obtain that specialization is an equilibrium if

$$
\Upsilon \leq\left[\left[\frac{1-\beta}{\beta}\right]^{\beta}+\left[\frac{\beta}{1-\beta}\right]^{1-\beta}\right] \alpha^{\beta}\left[\frac{\left(1-\phi_{\mathrm{a}}-\phi_{\mathrm{m}}\right)}{\left(\phi_{\mathrm{m}}(1-\tau)+\phi_{\mathrm{a}}\right)}\right]^{1-\beta}(1-\tau) \pi
$$

Otherwise, there will be diversification. Naturally, ceteris paribus, for favorable enough terms of trade, the economy will specialize in the production of primary goods.

\section{Diversification and trade}

Using 1,2, 4,5, 7 and imposing $p_{\mathrm{m}}^{d}=p_{\mathrm{m}}$ and $p_{\mathrm{a}}^{d}=(1-\tau) p_{\mathrm{a}}$, we solve for the endogenous variables $\kappa$ and $\lambda$.

From the conditions 1 and 2, we obtain $\lambda$ as an increasing function of $\kappa$ :

$$
\lambda=\left[\frac{\alpha}{\beta}\left(\frac{1}{1-\kappa}\right)^{1-\alpha}(1-\tau) \frac{\pi}{\Upsilon}\right]^{\frac{1}{1-\beta}} \kappa
$$

From 4, 5 and 7 we deduce:

$$
\frac{\lambda}{(1-\lambda)}+\left(\frac{\pi}{\Upsilon}\right)^{\frac{\beta}{1-\beta}} \frac{(1-\kappa)^{\frac{\alpha-\beta}{1-\beta}}}{(1-\lambda)}\left[\frac{\alpha}{\beta}(1-\tau)\right]^{\frac{\beta}{1-\beta}}=\frac{\phi_{\mathrm{m}}+\frac{\phi_{\mathrm{a}}}{(1-\tau)}}{1-\phi_{\mathrm{a}}-\phi_{\mathrm{m}}}(1-\beta) .
$$

If $\beta>\alpha$, then the left-hand side of the former expression is increasing in $\kappa$, whereas the right-hand side is constant. Thus, there is at most one value of $\kappa$ that satisfies this expression; $\lambda^{*}$ and $\kappa^{*}$ denote the shares that satisfy Eq. 11.

Proposition 1 In the diversification and trade equilibrium, an improvement in the terms of trade or a reduction in the export tax will lead to lower values of $\lambda^{*}$ and $\kappa^{*}$.

The solution is a steady-state equilibrium if the country exports the primary good and, at the same time, produces a positive amount of the manufactured good. The conditions for diversification were explained in Sect. 7.1.2.

Positive exports of the agricultural good implies: 


$$
\frac{c_{\mathrm{a}}}{K^{\alpha} T^{1-\alpha} A} \leq(1-\kappa)^{\alpha}
$$

In terms of the exogenous variables, this condition becomes:

$$
\frac{\phi_{\mathrm{a}}(1-\beta)}{\left(1-\phi_{\mathrm{a}}-\phi_{\mathrm{m}}\right)(1-\tau)} \frac{\Upsilon}{\pi} \leq \frac{\left(1-\kappa^{*}\right)^{\alpha}}{\left(1-\lambda^{*}\right)}\left(\frac{\lambda^{*}}{\kappa^{*}}\right)^{\beta} .
$$

\section{Reversal of the pattern of trade}

Using the same approach as in Sect. 7.1.3 but setting $\tau=0$, we solve for the endogenous variables. In this case, the solution is a steady-state equilibrium if the exports of the manufacturing good are positive, i.e., if $c_{\mathrm{a}}\left(K^{\alpha} T^{1-\alpha} A\right)^{-1}>(1-\kappa)^{\alpha}$. In terms of the exogenous variables, this condition becomes:

$$
\frac{\phi_{\mathrm{a}}(1-\beta)}{\left(1-\phi_{\mathrm{a}}-\phi_{\mathrm{m}}\right)} \frac{\Upsilon}{\pi}>\frac{\left(1-\kappa^{*}\right)^{\alpha}}{\left(1-\lambda^{*}\right)}\left(\frac{\lambda^{*}}{\kappa^{*}}\right)^{\beta} \text {. }
$$

\section{Graphical representation}

Given a set of parameters $\Upsilon, \phi_{\mathrm{a}}, \phi_{\mathrm{m}}, \alpha$ and $\beta$ with $\beta>\alpha, 0<\phi_{\mathrm{a}}, 0<\phi_{\mathrm{m}}$ and $\phi_{\mathrm{m}}+\phi_{\mathrm{a}}<1$, we can map each pair $(\pi, \tau)$ to one of the steady states above. Assuming $\beta>\alpha$, Fig. 1 in Sect. 3.1 shows the different regions in the $(\pi, \tau)$ space. The frontier between the reversal of trade and autarky regions is given by the autarky price equation:

$$
p_{\text {aut }}=\frac{\beta^{\beta}}{\alpha^{\alpha}}\left(\phi_{\mathrm{m}} \beta+\phi_{\mathrm{a}} \alpha\right)^{\alpha-\beta} \phi_{\mathrm{a}}^{1-\alpha}\left(\frac{(1-\beta)}{\left(\left(1-\phi_{\mathrm{a}}-\beta \phi_{\mathrm{m}}\right)\right)}\right)^{1-\beta} \Upsilon .
$$

The autarky region and the diversification and trade region are delimited by the level of $\tau$ that makes exports equal to zero:

$$
\tau=1-\frac{p_{\text {aut }}}{\pi}
$$

The specialization and diversification regions are separated by the points at which the marginal firm is indifferent to producing the first unit of the manufactured good or not:

$$
\pi=\frac{\left[\frac{\left(\phi_{\mathrm{m}}(1-\tau)+\phi_{\mathrm{a}}\right)}{\left(1-\phi_{\mathrm{a}}-\phi_{\mathrm{m}}\right)}\right]^{1-\beta} \Upsilon}{\left[\left[\frac{1-\beta}{\beta}\right]^{\beta}+\left[\frac{\beta}{1-\beta}\right]^{1-\beta}\right] \alpha^{\beta}} \frac{1}{(1-\tau)}
$$




\section{The political economy of protectionism}

The tax rate $\tau$ affects the prices and resource allocation of the economy. As we show below, the real remuneration of some factors of production increases with $\tau$, while the real remuneration of other factors decreases. Therefore, unless all economic agents are equally endowed, changes in the level of protectionism could have major distributional consequences. In this section, we derive the preferences of the different economic groups with regard to the policy variable $\tau$ under the main assumption that each economic agent has only one source of income. In our analysis, we consider three time horizons: the short, medium and long terms. In the short run, no reallocation of factors takes place. In the medium run, only labor is allowed to move between the secondary and the tertiary sector. In the long run, all mobile factors can be reallocated and the economy can fully adjust to its new equilibrium. Although we may assume that inputs are fixed within a sector, they are mobile across different firms within that sector. Thus, competition among different firms within a sector drives input prices to equalize the value of their marginal product.

While we do not set up a formal model of political competition that determines the evolution of the policy variable $\tau$, we do stress the political tensions that this model generates. We use these results to articulate our discussion on the rise and fall of protectionism in Argentina and the underlying distributional conflict.

Under autarky, or when the patterns of trade are such that the country exports manufactured goods, the tax on exports of primary goods has no effect whatsoever. We might think that the government could also tax the exports of manufactured goods. However, we do not delve into those issues simply because we do not think that they will shed any light on the main topic of this paper. So, we assume that the economy is always in one of the two other possible scenarios in which $\tau$ matters: either close to a steady state in which the economy specializes in the production of primary goods, or close to a steady state in which there is diversification of production and the country exports primary goods.

\section{The demand for protectionism}

In this section, we derive the effects of protectionism and changes in the terms of trade on the real remunerations of the factors of production. We log-linearize the model to derive the effect of protectionism in the short and medium run. The loglinearization is around an initial allocation. This initial allocation might be a steadystate equilibrium, in which case it is determined by $\pi$ and $\tau$; however, the argument follows through for any initial allocation determined also by $\kappa$ and $\lambda$.

The zero profit condition in the primary sector implies:

$$
a_{\mathrm{a}}=(1-\alpha) t+\alpha k_{\mathrm{a}},
$$

where $a_{\mathrm{a}}=d p_{\mathrm{a}}^{d} / p_{\mathrm{a}}^{d}$ is the percentage variation in the domestic price of the agricultural good, $t=d q / q$ denotes the percentage variation in the rent of the land and $k_{\mathrm{a}}=d r_{\mathrm{a}} / r_{\mathrm{a}}$ is the percentage variation in the return to capital in the primary sector. 
Since, in the short and medium run, capital is not mobile between sectors, it will be useful to employ different notations for the capital invested in the primary and secondary sectors. Finally, $\alpha$ is the share of capital in the total cost of production in the primary sector. Homotheticity of the production function implies that $\alpha$ is a function only of input prices. Moreover, under the assumption of a Cobb-Douglas technology, $\alpha$ is invariant. Similarly, in the manufacturing sector, we have:

$$
m_{\mathrm{m}}=l_{\mathrm{m}}(1-\beta)+k_{\mathrm{m}} \beta,
$$

where $m_{\mathrm{m}}=d p_{\mathrm{m}}^{d} / p_{\mathrm{m}}^{d}$ is the percentage variation in the domestic price of the manufactured good, $l_{\mathrm{m}}=d w_{\mathrm{m}} / w_{\mathrm{m}}$ denotes the percentage variation in wages and $k_{\mathrm{m}}=d r_{\mathrm{m}} / r_{\mathrm{m}}$ is the percentage variation in the return to capital in the secondary sector. As before, $\beta$ is the share of capital in the total cost of production. We continue to assume that $\beta \geq \alpha$; that is, we assume that capital is used more intensively in the secondary sector. Though this last assumption is not crucial, it will help us to solve some ambiguities later on. Finally, for the service sector, we have:

$$
n=l_{\mathrm{n}},
$$

where $n$ and $l_{\mathrm{n}}=d w_{\mathrm{n}} / w_{\mathrm{n}}$ are the respective percentage variations in the prices of the service good and the wages paid in that sector.

Cobb-Douglas preferences ensure that the percentage increase in expenditures of the three goods are the same: $a_{\mathrm{a}}+\mathrm{c}_{\mathrm{a}}=m_{\mathrm{m}}+c_{\mathrm{m}}=c_{\mathrm{n}}+n$, where $c_{i}$ denotes the percentage variation in the consumption of good $i$. For any agent, the indirect utility function is given by:

$$
\ln w-\sum_{i=1}^{3} \phi_{i} \ln p_{i}^{d},
$$

where $w$ denotes the income of the individual. Notice that we can construct an exact "price index" to account for the effect of price changes in total utility. We use this price index to deflate all the nominal variables of the economy.

$$
p=a_{c} \phi_{a}+m_{c} \phi_{m}+n_{n}\left(1-\phi_{a}-\phi_{m}\right) \text {. }
$$

In our model, the government changes domestic relative prices by taxing trade. The domestic price of the agricultural good is then given by $p_{\mathrm{a}}^{d}=p_{\mathrm{a}}(1-\tau)$. Taking $\operatorname{logs}$ and denoting $t_{\mathrm{a}}=d \tau_{\mathrm{a}} /\left(1-\tau_{\mathrm{a}}\right)$, we obtain:

$$
a_{\mathrm{a}}=a_{i}-t_{\mathrm{a}} .
$$

For the manufactured good, its domestic price is given by $m_{\mathrm{m}}=m_{i}$. The economy budget constraint is: $p_{\mathrm{m}} Y_{\mathrm{m}}+p_{\mathrm{a}} Y_{\mathrm{a}}=p_{\mathrm{m}} C_{\mathrm{m}}+p_{\mathrm{a}} C_{\mathrm{a}}$. Log-linearizing this equation around the initial values, we have:

$$
\left(m_{i}+y_{m}\right)\left(1-\chi_{a}\right)+\left(a_{i}+y_{a}\right) \chi_{a}=\left(c_{m}+m_{i}\right)\left(1-\gamma_{a}\right)+\left(a_{i}+c_{a}\right) \gamma_{a},
$$

where $y_{i}=d Y_{i} / Y_{i}$ and $\gamma_{\mathrm{a}}$ is the share of the agricultural good in total expenditure on tradable goods, evaluated at international prices. The parameter $\chi_{\mathrm{a}}$ is the share of the 
production of the agricultural good in the total value of the domestic production of tradable goods at international prices. If the country exports the primary good, then $\chi_{\mathrm{a}}>\gamma_{\mathrm{a}}$.

The variable $\gamma_{\mathrm{a}}$ can be re-written in terms of parameters of the model:

$$
\begin{aligned}
\gamma_{\mathrm{a}} & =\frac{p_{\mathrm{a}} C_{\mathrm{a}}}{p_{\mathrm{m}} C_{\mathrm{m}}+p_{\mathrm{a}} C_{\mathrm{a}}} \\
& =\frac{\phi_{\mathrm{a}}}{(1-\tau) \phi_{\mathrm{m}}+\phi_{\mathrm{a}}} .
\end{aligned}
$$

Similarly, for $\chi_{\mathrm{a}}$,

$$
\chi_{\mathrm{a}}=\frac{1}{1+\frac{\lambda^{1-\beta} \kappa^{\beta}}{\pi(1-\kappa)^{\alpha}} \Upsilon} .
$$

We now consider the adjustment of the economy to changes in international prices and taxes, assuming different speeds of adjustment for the mobile factors of production.

Short run In the short run, all factors of production are reallocated only within the sector where they were previously employed. Given the Cobb-Douglas production function and the zero profit condition, we know that the flow of earnings accruing to landlords is equal to a fraction of the value of the total production of the primary sector. Given that land is not reallocated, the percentage increase in the rental rate for land is equal to:

$$
t=a_{\mathrm{a}}+y_{\mathrm{a}} .
$$

Since, in the short run, the allocation of capital in the primary sector does not change, the following capital rent equation holds:

$$
k_{\mathrm{a}}=a_{\mathrm{a}}+y_{\mathrm{a}} .
$$

Similarly, in the manufacturing sector, the following capital rent and wage equations hold:

$$
\begin{aligned}
& k_{\mathrm{m}}=m_{\mathrm{m}}+y_{\mathrm{m}}, \\
& l_{\mathrm{m}}=m_{\mathrm{m}}+y_{\mathrm{m}} .
\end{aligned}
$$

Finally, total expenditure on services has to equal the total wages paid in the sector. Noting that the production of services has to equal consumption, we find that:

$$
l_{\mathrm{n}}=c_{\mathrm{n}}+n_{\mathrm{n}} .
$$

Let us now consider the effects of an increase in the international price of the primary good. Given that there is no factor reallocation, the output of the three goods remains constant. Without government intervention, the domestic price of the 
primary good and the return to the factors employed in the primary sector increase in proportion to the increase in the terms of trade. Since the agents owning those resources are wealthier, they increase their demand for services, which drives up wages in the tertiary sector. Workers in the service sector enjoy an increase in their nominal wages that is proportional to the economy's degree of specialization: $\chi_{\mathrm{a}}$. Finally, the factors employed in the manufacturing sector do not receive any increase in their remunerations. The consumer price index rises, since the prices of both the primary and the tertiary goods increase. Proposition 2 summarizes these results.

Proposition 2 In the short run, an increase in the international price of the agricultural good (i.e., an improvement in the terms of trade) raises the real remuneration received by landowners, capitalists in the primary sector and service workers. However, it reduces the real remuneration of workers and capitalists in the manufacturing sector.

Notice that the real effects of an increase in the international price of the agricultural good are identical to those of a decrease in the international price of the manufactured good. Agents may demand policies that will protect them from changes in international prices. Proposition 3 deals with the effects of taxes on exports.

Proposition 3 In the short run, protectionist policies reduce the real remuneration of landowners, capitalists in the primary sector and service workers. If $\phi_{\mathrm{a}}>0$, protectionist policies will raise the real remuneration of workers and capitalists in the secondary sector.

Medium run In the medium run, labor is allowed to move across industries, so wages equalize across sectors. Log-linearizing the market clearing condition for labor, we have:

$$
\lambda\left(m_{\mathrm{m}}+y_{\mathrm{m}}\right)+(1-\lambda)\left(n_{\mathrm{n}}+y_{\mathrm{n}}\right)=l .
$$

This equation and the condition that $l_{\mathrm{m}}=l_{\mathrm{n}}=l$ replace the two equations of wage determination obtained for the case of the short-run equilibrium. Now, the short-run effects of an improvement in the terms of trade include an increase in the production of services and a decrease in the total production of manufactures. Since there is no factor adjustment in the primary sector, the remuneration of capital and land increase by the same proportion as the terms of trade. This generates an upward shift in the demand for services which is met both by an increase in its equilibrium price and by a displacement of labor from the secondary to the tertiary sector. The manufacturing sector uses less labor, and the return to capital in this sector therefore falls. Overall, consumption of the primary good decreases, and consumption of the manufactured and service goods increases.

Proposition 4 In the medium run, an improvement in the terms of trade increases the real remuneration received by landowners and capitalists in the primary sector. 
It harms capitalists in the manufacturing sector. The real wage increases if and only if:

$$
\chi_{\mathrm{a}}(1-\lambda)>\frac{\phi_{\mathrm{a}}}{\left(\phi_{\mathrm{m}} \beta+\alpha_{\mathrm{a}}\right)} .
$$

Higher demand for services increases wages in that sector and attracts workers from the manufacturing sector, raising wages across the economy. However, the equilibrium increase in wages may fall short of compensating the negative welfare effect of the increase in the price of the agricultural good. The more specialized the economy in the primary and tertiary sector (i.e., a higher $\chi_{\mathrm{a}}$ and a lower $\lambda$ ), the more likely is it that real wages will increase in the medium run. This is because, in such cases, the upward shift in demand for labor in the service sector is stronger. Thus, notice that, if the economy is already industrialized, an increase in the terms of trade may harm workers even in the medium run.

Proposition 5 In the medium run, protectionist policies reduce the real remuneration of landowners and capitalists in the primary sector. If $\phi_{\mathrm{a}}>0$, protectionist policies increase the real remuneration of capitalists in the manufacturing sector. If $\phi_{\mathrm{a}}>0$, workers' welfare increases if and only if:

$$
(1-\lambda)\left[(1-\beta) \chi_{\mathrm{a}}+\beta \frac{\phi_{\mathrm{a}}+\phi_{\mathrm{m}}}{\phi_{\mathrm{a}}+(1-\tau) \phi_{\mathrm{m}}}\right] \leq 1 .
$$

Workers' welfare increases with protectionism if the economy is beyond a given level of industrialization. In this case, workers may ally with capitalists in the secondary sector to demand protectionist policies. If $\tau=0$, this condition is satisfied as soon as the economy starts producing in the secondary sector. A higher tax rate implies that the condition will be met for higher $\lambda$ and lower $\chi_{\mathrm{a}}$. In Fig. 3, we find the pairs $(\pi, \tau)$, such that workers are indifferent to whether there is more or less protection, since movement in either direction will improve workers' welfare in the medium run.

Moreover, we expect that, the more industrialized the economy is, the larger the share of workers who will be employed in the secondary sector and, hence, by virtue of Proposition 2, the larger the share of workers who will also benefit from protectionist policies in the short run.

Long run In the long run, the economy will tend toward a new steady state. Therefore, it is useful to analyze the effects of protectionism based on the results obtained in Sect. 7.1.

A full analysis of the long-run solution for this economy is fairly complicated. Nevertheless, the two propositions set out below suffice for our purposes in this paper. We focus only on the preferences for protectionism of landlords and workers, since we assume that capitalists are concerned only with policies in the short and medium run, when their capital is sunk in one particular activity. We assume that 
the economy is initially in the specialization and trade or in the diversification and trade regions (i.e., it exports the primary good). Otherwise, changes in the export tax rate would not have any effect.

Proposition 6 In the long run, landlords benefit from an improvement in the terms of trade and from a reduction in export taxes.

Proposition 7 If the economy is specialized, then, in the long run, workers benefit from an improvement in the terms of trade and from a reduction in export taxes. There is always a $\pi^{*}$ high enough so that workers are better off at $\tau=0$.

\section{Constant-elasticity-of-substitution (CES) preferences and technology in Autarky}

In this appendix, we derive a log-linearization around the autarky equilibrium for a CES economy. The results of this section are referred to in Sect. 3.4.

The production functions of the agricultural and manufactured goods are, respectively:

$$
\begin{aligned}
& A\left(\xi_{T} T^{\rho_{1}}+\xi_{K, \mathrm{a}} K_{A}^{\rho_{1}}\right)^{1 / \rho_{1}}, \\
& M\left(\xi_{L} L_{M}^{\rho_{2}}+\xi_{K, \mathrm{~m}} K_{M}^{\rho_{2}}\right)^{1 / \rho_{2}},
\end{aligned}
$$

where $A$ and $M$ are productivity parameters, $\xi_{i}^{\prime} s$ are share parameters and $\left(1-\rho_{i}\right)^{-1}$ for $i \varepsilon\{1,2\}$ are the elasticity of substitution. Notice that:

\begin{tabular}{lll}
\hline$\rho_{i}$ & Case & Elasticity of substitution \\
\hline$-\infty$ & Leontieff: perfect complements & 0 \\
0 & Cobb-Douglas & 1 \\
1 & Perfect substitutes & $\infty$ \\
\hline
\end{tabular}

The production function for services is still $Y_{\mathrm{N}}=N L_{\mathrm{N}}$, where $\mathrm{N}$ is a productivity parameter.

Consumer's preferences are represented by:

$$
\left(\phi_{1} c_{A}^{\rho_{d}}+\phi_{2} c_{M}^{\rho_{d}}+\left(1-\phi_{1}-\phi_{2}\right) c_{\mathrm{N}}^{\rho_{d}}\right)^{1 / \rho_{d}} .
$$

We are interested in the effect of the exogenous variables $(\hat{T}, \hat{K}, \hat{L}, \hat{A}, \hat{M}, \hat{N}$, where $\hat{T}=d T / T$ ) on the capital and labor employment share $\hat{\lambda}$ and $\hat{\kappa}$. The following table shows the sign of these effects as a function of the elasticity of substitutions $\rho_{1}, \rho_{2}$ and $\rho_{d}$. For instance, the first row shows that the effect of an increase in the amount of land, $\hat{T}$, on $\kappa$ (i.e., $\mathrm{d} \hat{\kappa} / \mathrm{d} \hat{T}$ ) has the same sign as $\rho_{1}-\rho_{d}$, whereas the effect on $\lambda$ (i.e., $\mathrm{d} \hat{\lambda} / \mathrm{d} \hat{T})$ has the same sign as $-\left(\rho_{2}-\rho_{d}\right)\left(\rho_{1}-\rho_{d}\right)$. The next rows show the sign of the effect for the other five exogenous variables. 


\begin{tabular}{lll}
\hline & $d \hat{\kappa}$ & $d \hat{\lambda}$ \\
\hline$d \hat{T}$ & $\rho_{1}-\rho_{d}$ & $-\left(\rho_{2}-\rho_{d}\right)\left(\rho_{1}-\rho_{d}\right)$ \\
$d \hat{K}$ & (footnote) & $\rho_{d}-\rho_{2}$ \\
$d \hat{L}$ & $\rho_{d}-\rho_{2}$ & $\rho_{2}-\rho_{d}$ \\
$d \hat{A}$ & $-\rho_{d}$ & $\left(\rho_{2}-\rho_{d}\right) \rho_{d}$ \\
$d \hat{M}$ & $\rho_{d}$ & $\rho_{d}$ \\
$d \hat{N}$ & $\left(\rho_{2}-\rho_{d}\right) \rho_{d}$ & $-\rho_{d}$ \\
\hline
\end{tabular}

(footnote table) The sign of the effect of the endowment of capital on the share of capital employed in the manufacturing sector is the same as a quadratic function of $\rho_{1}, \rho_{2}$ and $\rho_{d}$ that depends on parameters $\alpha, \beta$ and $\lambda$.

In Sect. 3.4.1, we analyze the effect of $\hat{L}$ and $\hat{A}$ (population growth and productivity growth in agriculture) on $\hat{\kappa}$ and $\hat{\lambda}$.

We notice that $\mathrm{d} \hat{\lambda} / \mathrm{d} \hat{L}$ has the same sign as $\rho_{2}-\rho_{d}$, i.e., population growth $L$ will decrease $\lambda$ if the elasticity of substitution in consumption is greater than in the production of manufactures $\left(\rho_{d}>\rho_{2}\right)$. We also state that the effect on $\kappa$ will be the opposite: $\mathrm{d} \hat{\kappa} / \mathrm{d} \hat{L}$ has the same sign as $\rho_{d}-\rho_{2}$.

Similarly, in the table we read that $\mathrm{d} \hat{\lambda} / \mathrm{d} \hat{A}$ has the same sign as $\left(\rho_{2}-\rho_{d}\right) \rho_{d}$, which corresponds with what was stated in Sect. 3.4.1: Higher productivity in the agricultural sector will decrease $\lambda$ if the elasticity of substitution in consumption is greater than 1 and than that in the production of manufactures (i.e., $\rho_{d}>0$, $\left.\rho_{d}>\rho_{2}\right)$. Similarly, $\mathrm{d} \hat{\kappa} / \mathrm{d} \hat{A}$ will have the same sign as $-\rho_{d}$ : the share of capital, $\kappa$, will decrease if the elasticity of substitution in consumption is greater than 1 .

\section{Appendix 2}

In this appendix, we provide evidence supporting our argument that trade policies are still a key component of electoral competition and that the coalitions vote as suggested by our model. We look at the developments of 2008, when the government's attempt to increase export duties was met with a nationwide lockout by farming associations and mass demonstrations in urban centers. We also use the results of the 2007 presidential election and the 2009 legislative elections to compare how the incumbent party-Frente para la Victoria (FPV), a political coalition including the Justicialist Party-fared before and after it publicly confronted the pro-agriculture coalition.

Export duties were almost non-existent during the 1990s, but were raised after the devaluation in 2002 to capture windfall profits from exporting firms. Over time, they became a reliable source of revenue for the federal government and a handy mechanism for keeping domestic food prices in check. For example, the tax rate on oilseeds exports was raised from $0.5 \%$ in 2001 to $17.5 \%$ in 2002.

The FPV is an electoral alliance that was founded in 2003 within the Justicialist (Peronist) Party by Néstor Kirchner, who ran for President the same year. The party 
won the election with an unimpressive $22 \%$ of the vote. However, in the legislative election of 2005, the FPV secured a majority in both houses of Congress, and in the presidential election of 2007 , it obtained $45 \%$ of the vote- $22 \%$ more than its nearest rival. In 2007 the FPV candidate was Mrs. Cristina Fernández de Kirchner, the incumbent president's wife.

Up to 2008, the FPV government had increased export duties substantially. Export duties for oilseeds reached 32\% during 2007. However, the government also kept the local currency undervalued, which benefitted exporting sectors.

In March 2008, the international price of oilseeds reached record levels. The government attempted to introduce a new sliding-scale taxation system for soybean and sunflower exports that would raise duties to $44 \%$ of the prices of that time. The announcement was met by a nationwide lockout by farming firms. Government officials and government-affiliated labor unionists denounced the lockout as being staged by big farming companies and having no popular support. However, the proagriculture movement drew support from a large share of the middle-class population that gathered in urban centers to oppose the new tax scheme. After 4 months of political struggles that eroded the government's approval ratings and fractured the cohesion among FPV members of Congress, the proposal was defeated in the Senate, despite the fact that the FPV had a majority in both houses of Congress. The legislative elections of 2009 mirrored the major setback suffered by the government the previous year. The FPV obtained $30 \%$ of the vote, $15 \%$ less than in the previous election, and lost its majority in both houses.

During the events of 2008, the FPV took a clear stance in the distributional conflict and appealed to the protectionist sentiment of its constituents. These appeals, which had been so effective during the second half of the twentieth century, resulted in a sharp reduction in approval ratings and votes.

Under the predictions of our model, agents with vested interests in the primary sector would be less likely to vote for the FPV after the party revealed its position concerning the distributional conflict. If agents voted according to their interests and trade policy was an important component of electoral competition, we should observe a sharper fall in FPV votes in districts where the majority of voters derive their income from the primary or the tertiary sector. We test that prediction by comparing the percentages of votes that the FPV received in 2007 and 2009 in different districts, or Partidos, of the Province of Buenos Aires.

For each of the 134 districts of Buenos Aires, we obtain a measure of the ratio of the population that should support free trade. Using 2001 census data, all individuals that derive their income from activities in the primary sector and all other individuals with some secondary schooling who are not employed in the manufacturing sector are classified as "free traders". All individuals who derive their income from the manufacturing sector and those individuals who do not have at least some secondary schooling and are not employed in the primary sector are classified as "protectionists".

In our model, we have abstracted from skill heterogeneity among workers. However, if skilled workers are employed more intensively in the tertiary sector, then we might expect them to support free trade. Similarly, if unskilled workers are employed intensively in the secondary sector, they should support protectionism 
(see Galiani et al. 2010). The inclusion of educational attainment in the classification captures such heterogeneity to some extent.

Suppose that, in district $d$, free traders and protectionists voted for FPV with probabilities $\pi_{d, f}$ and $\pi_{d, p}$, respectively. Then, if the proportion of free traders in district $d$ is $f_{d}$, the total share of votes of FPV is: $v_{d} \equiv \pi_{d, p}+\left(\pi_{d, f}-\pi_{d, p}\right) f_{d}$. This identity holds for any classification of free traders. Now, we model $\pi_{d, f}=\pi\left(\beta_{f}, \varepsilon_{d}\right)$, i.e., the probability $\pi_{d, f}$ is equal to a monotonic function of a parameter $\beta_{f}$ and a disturbance $\varepsilon_{d}$ that is common to $\pi_{d, f}$ and $\pi_{d, p}$. If we assume that $\pi(\beta, \varepsilon)=\beta+\varepsilon$ and that $E(\varepsilon \mid f)=0$, we can estimate $\beta_{f}$ and $\beta_{p}$ consistently by OLS, since $v_{d}=\beta_{p}+\left(\beta_{f}-\beta_{p}\right) f_{d}+\varepsilon_{d}$. The parameters $\beta_{i}$ can be interpreted as the expected probability that an agent of type $i$ votes for the FPV, where the expectation is taken across districts. The estimation results are shown below:

\begin{tabular}{|c|c|c|c|c|c|c|c|c|}
\hline & \multicolumn{4}{|c|}{2007 Presidential election } & \multicolumn{4}{|c|}{2009 Legislative election } \\
\hline & Coef. & SE & $95 \% \mathrm{C}-2-x$ & & Coef. & SE & $95 \% \mathrm{CI}$ & \\
\hline Free traders & 0.205 & 0.042 & 0.122 & 0.288 & -0.086 & 0.041 & -0.167 & -0.005 \\
\hline Protectionists & 0.858 & 0.058 & 0.742 & 0.974 & 0.774 & 0.057 & 0.660 & 0.888 \\
\hline
\end{tabular}

Notice that both protectionists and free traders were less likely to vote for the FPV in 2009 than they were in 2007. However, the drop in the probability for free traders is more pronounced. To test the null hypothesis of an identical drop for both groups, we regress the difference in FPV votes between 2009 and 2007 on the share of free traders. Notice that

$$
v_{d, 09}-v_{d, 07}=\left(\beta_{p, 09}-\beta_{p, 07}\right)+\left(\beta_{f, 09}-\beta_{f, 07}-\beta_{p, 09}+\beta_{p, 07}\right) f_{d}+\varepsilon_{d} .
$$

We find some evidence against the hypothesis of an identical drop in probabilities: $p$ value 0.067 .

The negative coefficient for free traders in 2009 suggests that our linear specification of $\pi(\beta, \varepsilon)$ may be incorrect. Therefore, we try a different specification: $\pi(\beta, \sigma, \varepsilon)=\Phi(\beta+\sigma \varepsilon)$, where $\Phi$ is the cumulative density function of a standard normal and $\sigma$ is a parameter to be estimated. If we assume that $\varepsilon$ is normally distributed, we can estimate $\beta_{f}, \beta_{p}$ and $\sigma$ by maximum likelihood. $\Phi\left(\beta_{i}\right)$ can be interpreted as the median probability that an agent of type $i$ will vote for the FPV, where the median is taken over the distribution of probabilities $\pi_{d, i}$ across districts. The estimation results are shown below:

\begin{tabular}{lccccccc}
\hline & \multicolumn{3}{l}{2007 Presidential election } & & \multicolumn{3}{l}{ 2009 Legislative election } \\
\cline { 2 - 3 } \cline { 7 - 8 } & Coef $\beta_{i}$ & SE & $\Phi\left(\beta_{i}\right)$ & & Coef $\beta_{i}$ & SE & $\Phi\left(\beta_{i}\right)$ \\
\hline Free traders & -1.030 & 0.142 & 0.152 & & -2.567 & 0.336 & 0.005 \\
Protectionists & 1.437 & 0.288 & 0.925 & & 0.385 & 0.051 & 0.650 \\
Sigma & 0.344 & 0.209 & & & 0.438 & 0.099 & \\
\hline
\end{tabular}


Now, we obtain that free traders voted for the FPV with positive probability. Moreover, it is still true that the probability of voting for the FPV drops more in the case of free traders.

The estimated probabilities seem too extreme, i.e., our classification seems to imply a strong negative correlation between the proportion of "free traders" and FPV votes by district. It may be the case that, irrespective of their classification, individuals in more agricultural districts are less likely to vote for the FPV, independently of their source of income. In that case, $f_{d}$ and $\varepsilon_{d}$ are negatively correlated and our results would be unable to distinguish between individual and district-level political attitudes. However, even if that is the case, the fact that the aggregate source of income affects political attitudes at the district level is also consistent with the predictions of our model: service workers will support policies that increase the aggregate income of their district and boost the demand for their services.

One might suspect that these differences in political attitudes are driven exclusively by the heterogeneity in educational attainment across districts. However, if we classify individuals solely on the basis of their educational attainment, we obtain strikingly different results. The estimated probability for unskilled individuals (no secondary education) falls drastically, while the probability for skilled workers remains almost constant. Unskilled individuals employed in the primary sector were less likely to vote for the FPV in 2009, while skilled individuals employed in the secondary sector partially compensated for the loss of votes from skilled individuals employed in the tertiary sector.

\begin{tabular}{|c|c|c|c|c|c|c|c|c|}
\hline \multirow[b]{3}{*}{ Skilled } & \multicolumn{4}{|c|}{2007 Presidential election } & \multicolumn{4}{|c|}{2009 Legislative election } \\
\hline & \multirow{2}{*}{$\frac{\text { Coef. }}{0.318}$} & \multirow{2}{*}{$\frac{\mathrm{SE}}{0.031}$} & \multicolumn{2}{|c|}{$95 \% \mathrm{CI}$} & \multirow{2}{*}{$\frac{\text { Coef. }}{0.288}$} & \multirow{2}{*}{$\begin{array}{l}\mathrm{SE} \\
0.037\end{array}$} & \multicolumn{2}{|c|}{$95 \% \mathrm{CI}$} \\
\hline & & & 0.257 & 0.379 & & & 0.215 & 0.360 \\
\hline Unskilled & 0.662 & 0.036 & 0.590 & 0.733 & 0.253 & 0.043 & 0.169 & 0.337 \\
\hline
\end{tabular}

For comparison purposes, we present the maximum likelihood results for the specification: $\Phi(\beta+\sigma \varepsilon)$. Notice how similar the estimated probabilities are in the two specifications.

\begin{tabular}{lccccccc}
\hline & \multicolumn{2}{l}{2007 Presidential election } & & & \multicolumn{3}{l}{ 2009 Legislative election } \\
\cline { 2 - 3 } \cline { 7 - 8 } & Coef $\beta_{i}$ & SE & $\Phi\left(\beta_{i}\right)$ & & Coef $\beta_{i}$ & SE & $\Phi\left(\beta_{i}\right)$ \\
\hline Skilled & -0.491 & 0.087 & 0.312 & & -0.569 & 0.110 & 0.285 \\
Unskilled & 0.435 & 0.099 & 0.668 & & -0.698 & 0.138 & 0.243 \\
Sigma & 0.207 & 0.073 & & & 0.262 & 0.062 & \\
\hline
\end{tabular}

This provides support for our claim that the source of income is a key determinant of individuals' political attitudes. In particular, individuals with vested interests in the primary sector and skilled individuals in the tertiary sector support free trade policies. Individuals whose source of income is linked to the 
manufacturing sector support protectionist policies. Moreover, this exercise also suggests that individuals took into account the ideological and political stance of the FPV with respect to protectionism. Those who opposed protectionism were less likely to vote for the FPV in 2009 than in 2007.

\section{References}

Acuña C, Galiani S, Tommasi M (2007) Understanding reforms: the case of Argentina. In: Fanelli JJ (ed) Understanding reform in Latin America. Palgrave-Macmillan, Basingstoke

Adelman J (1994) Frontier development: land, labour, and capital on the wheatlands of Argentina and Canada, 1890-1914. Clarendon Press, Oxford

Anderson K (1998) Are resource-abundant economies disadvantaged? Aust J Agric Resour Econ 42:1-23

Anderson K (2002) International trade and industry policies. CIES discussion paper 0216

Anderson K, Garnaut R (1987) Australian protectionism: extent, causes and effects. Allen \& Unwin, Sydney

Baldwin R, Martin P (1999) Two waves of globalization: superficial similarities, fundamental differences. NBER working paper 6904, National Bureau of Economic Research, Cambridge, MA

Cantón D (1968) Materiales para el estudio de la sociologa poltica en la Argentina. Mimeo, Buenos Aires

Clemens M, Williamson J (2002) Closed Jaguar, open dragon: comparing tariffs in Latin America and Asia before World War II. National Bureau of Economic Research, working paper 9401

Corden WM (1996) Protection liberalisation in Australia and abroad. Aust Econ Rev 29(2):141-154

Cortés-Conde R (1979) El progreso Argentino: 1880-1914. Editorial Sudamericana, Buenos Aires

Cortés-Conde R (1998) Progreso y Declinacion de La Economia Argentina: Un Analisis Historico Institucional. Fondo de Cultura Economica, Buenos Aires

Díaz-Alejandro CF (1970) Essays on the economic history of the Argentine republic. Yale University Press, New Haven

Díaz-Alejandro CF (1984) No less than one hundred years of Argentine economic history plus some comparisons. In: Ranis G, West R, Leirsenson M, Taft Morris C (eds) Trade, comparative development perspectives. Westview Press, Boulder, CO

Galiani S, Gerchunoff P (2003) The labor market. In: Della Paolera G, Taylor A (eds) A new economic history of Argentina. Cambridge University Press, Cambridge

Galiani S, Heymann D, Dabus C, Thome F (2008) On the emergence of public education in land-rich economies. J Dev Econ 86:434-446

Galiani S, Schofield N, Torrens G (2009) Factor endowments, democracy and trade policy divergence. J Pub Econ Theory 16:119-156

Galiani S, Heymann D, Magud N (2010) On the distributive effects of terms of trade shocks: the role of non-tradable goods. IMF working papers, pp 1-38

Garnaut R (2002) Australia: a case study of unilateral trade liberalisation. In: Bagwati J (ed) Going alone: the case for relaxed reciprocity in freeing trade. The MIT Press, Cambridge, pp 139-166

Gerchunoff P (1989) Peronist economic policies, 1946-55. In: DiTella G, Dornbusch R (eds) The political economy of Argentina. St Antony's series. Oxford University Press, Oxford, pp 1946-1983

Gerchunoff P, Fajgelbaum P (2006) Por que Argentina no fue Australia? Una Hipotesis sobre un Cambio de Rumbo. Editorial Siglo XXI, Argentina

Gerchunoff P, Llach L (2004) Entre la Equidad y el Crecimiento: Ascenso y Cada de la Economía Argentina, 1880-2002. Siglo XXI, Argentina

Gomez-Galvarriato A, Williamson J (2009) Was it prices, productivity or policy? Latin American industrialisation after 1870. J Lat Am Stud 41:663-694

HalperínDonghi T (1994) La Larga Agonia de la Argentina Peronista. Ariel, Argentina

Heymann D (1984) Precios relativos, riqueza y producción. Ens Econ 29:53-90

Hirst J (1979) La sociedad rural y la politica en Australia. In: Fogarty J, Gallo E, Dieguez H (eds) Argentina y Australia. Instituto Torcuato Di Tella, Buenos Aires, pp 1859-1930

Llach JJ (2002) La Industria, 1945-1976. In: Nueva Historia de la Nación Argentina. Academia Nacional de Historia, Editorial Planeta, Argentina 
Llach L (2006) Argentina y el mercado mundial de sus productos, 1920-1976. Estudios y Perspectivas Series, no. 35, Economic Commission for Latin America and the Caribbean (ECLAC)

Mallon RD, Sourrouille JV (1975) Economic policymaking in a conflict society: the Argentine case. Harvard University Press, Cambridge

North D (1990) Institutions, institutional change and economic performance. Cambridge University Press, New York

O’Donnell A (1977) Estado y Alianzas en la Argentina, 1956-1976. Desarro Econ 16(64):523-554

O'Rourke KH, Williamson JG (1999) Globalization and history: the evolution of a nineteenth-century Atlantic economy. The MIT Press, Cambridge

Rogowski R (1989) Commerce and coalitions: how trade affects domestic political alignments. Princeton University Press, Princeton

Spiller P, Tommasi M (2009) The institutional foundations of public policy in Argentina: a transactions cost approach. Cambridge University Press, Cambridge

Stolper WF, Samuelson PA (1941) Protection and real wages. Rev Econ Stud 9(1):58-73

Taylor AM (1994) Three phases of Argentine economic growth. NBER historical working paper, no. 60

Taylor AM (1997) Peopling the pampa: on the impact of mass migration to the River Plate, 1870-1914. Explor Econ Hist 34(1):100-132

Torre JC (2002) Introducción a los años Peronistas. In: Torre JC (ed) Nueva Historia Argentina. Editorial Sudamericana, Argentina

Villanueva J (1972) El origen de la industrialización Argentina. Desarrollo Económico 12:451-476

Waisman C (1987) Reversal of development in Argentina. Princeton University Press, Princeton

Williamson J (2002) Winners and losers over two centuries of globalization. NBER working paper 9161, National Bureau of Economic Research, Cambridge, MA 